\title{
Characteristics, seasonality and sources of carbonaceous and ionic components in the tropical aerosols from Indian region
}

\author{
C. M. Pavuluri ${ }^{1}$, K. Kawamura ${ }^{1}$, S. G. Aggarwal ${ }^{1,2}$, and T. Swaminathan ${ }^{3}$ \\ ${ }^{1}$ Institute of Low Temperature Science, Hokkaido University, N19 W8, Kita-ku, Sapporo 060-0819, Japan \\ ${ }^{2}$ National Physical Laboratory (Council of Scientific and Industrial Research), Dr. K. S. Krishnan Road, \\ New Delhi 110012, India \\ ${ }^{3}$ Department of Chemical Engineering, Indian Institute of Technology Madras, Chennai 600036, India
}

Received: 22 December 2010 - Published in Atmos. Chem. Phys. Discuss.: 3 February 2011

Revised: 2 August 2011 - Accepted: 5 August 2011 - Published: 11 August 2011

\begin{abstract}
To better characterize the tropical aerosols in Indian region, $\mathrm{PM}_{10}$ samples collected from Chennai, India $\left(13.04^{\circ} \mathrm{N} ; 80.17^{\circ} \mathrm{E}\right)$ were analyzed for carbonaceous and water-soluble ionic components. Concentration ranges of elemental carbon (EC) and organic carbon (OC) were $2.4-14 \mu \mathrm{g} \mathrm{m}^{-3}$ (ave. $6.5 \mu \mathrm{g} \mathrm{m}^{-3}$ ) and 3.2$15.6 \mu \mathrm{g} \mathrm{m}^{-3}$ (ave. $9.1 \mu \mathrm{g} \mathrm{m}^{-3}$ ) in winter samples whereas they were $1.1-2.5 \mu \mathrm{g} \mathrm{m}^{-3}$ (ave. $1.6 \mu \mathrm{g} \mathrm{m}^{-3}$ ) and $4.1-$ $17.6 \mu \mathrm{g} \mathrm{m}^{-3}$ (ave. $9.7 \mu \mathrm{g} \mathrm{m}^{-3}$ ) in summer samples, respectively. Concentration of secondary organic carbon (SOC) retrieved from EC-tracer method was $4.6 \pm 2.8 \mu \mathrm{g} \mathrm{m}^{-3}$ in winter and $4.3 \pm 2.8 \mu \mathrm{g} \mathrm{m}^{-3}$ in summer. OC accounted for $38.5 \pm 14 \%(n=49)$ of combined concentrations of carbonaceous and ionic components in $\mathrm{PM}_{10}$. We also found that $\mathrm{OC}$ concentrations are generally higher than those of $\mathrm{SO}_{4}^{2-}\left(8.8 \pm 2.5 \mu \mathrm{g} \mathrm{m}^{-3}\right.$ and $4.1 \pm 2.7 \mu \mathrm{g} \mathrm{m}^{-3}$ in winter and summer, respectively), which was the most abundant ionic species $(57 \%)$ followed by $\mathrm{NH}_{4}^{+}(15 \%)$ $>\mathrm{NO}_{3}^{-}>\mathrm{Cl}^{-}>\mathrm{K}^{+}>\mathrm{Na}^{+}>\mathrm{Ca}^{2+}>\mathrm{MSA}^{-}>\mathrm{Mg}^{2+}$. The mass fractions of EC, organic matter $(\mathrm{OM})$ and ionic species varied seasonally, following the air mass trajectories and corresponding source strength. Based on mass concentration ratios of selected components and relations of EC and OC to marker species, we found that biofuel/biomass burning is a major source of atmospheric aerosols in South and Southeast Asia. The high concentrations of SOC and WSOC/OC ratios (ave. $0.45 ; n=49$ ) as well as good correlations between SOC and WSOC suggest that the secondary production of organic
\end{abstract}

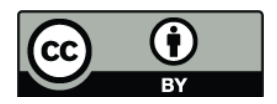

Correspondence to: K. Kawamura (kawamura@lowtem.hokudai.ac.jp) aerosols during long-range atmospheric transport is also significant in this region. This study provides the baseline data of carbonaceous aerosols for southern part of the Indian subcontinent.

\section{Introduction}

Elemental carbon (EC) and particulate organic matter (POM) contribute to $5-9 \%$ and $20-50 \%$ of the continental fine $\left(\mathrm{PM}_{2.5}\right)$ aerosol mass in mid-latitudes, respectively (Sillanpää et al., 2005). In tropical forested areas, POM alone contributes up to $90 \%$ (Kanakidou et al., 2005). EC is formed by fossil fuel combustion and biofuel/biomass burning (anthropogenic sources). POM, a complex mixture of numerous organic compounds, is directly emitted from anthropogenic sources or secondary formed through atmospheric oxidation of reactive organic gases and subsequent gas-toparticle conversion (Yu et al., 2004). In contrast, inorganic materials comprise up to $70 \%$ of the total aerosol mass emitted from both natural and anthropogenic sources (AliMohamed, 1991).

The atmospheric aerosols have an impact on climate as well as hydrological cycle and human health at local, regional and global scales (Ackerman et al., 2000; Menon et al., 2002; Ramanathan et al., 2001). The impacts of aerosols largely depend on their chemical composition. Elemental carbon (EC) is a strong absorber of solar radiation and causes both positive (warming) and negative (cooling) radiative forcing at top of the atmosphere and the surface, respectively (Haywood and Ramaswamy, 1998; Jacobson, 2001). In contrast, organic carbon (OC) and sulfate $\left(\mathrm{SO}_{4}^{2-}\right)$ are

Published by Copernicus Publications on behalf of the European Geosciences Union. 
highly reflective to light and thus cause cooling effect (Haywood and Ramaswamy, 1998; Kiehl and Briegleb, 1993). Further, water-soluble OC (WSOC) including dicarboxylic acids enhances the capability of aerosols as cloud condensation nuclei (CCN) (Kawamura and Usukura, 1993; Saxena et al., 1995; Sun and Aria, 2006; Miyazaki et al., 2009).

In South and Southeast Asia, pollutants are highly emitted to the atmosphere due to growing economies, particularly India (World Bank, 2000), and due to biomass burning including forest fires as well as widespread use of biofuels (dung cake, wood and agricultural waste) for cooking (Reddy and Venkataraman, 2002a, b; Tata Energy Research Institute, 1997). Conversely, heavily polluted atmospheres have been more often observed for last decades (Lelieveld et al., 2001), which cover a long-term dimming in the region that extends over the equatorial Indian Ocean (Ramanathan et al., 2001). For example, high mass loading $\left(\sim 6 \mu \mathrm{g} \mathrm{m}^{-3}\right)$ of organics have been reported in the atmospheric aerosols over the northern Indian Ocean whereas their concentrations were negligible south of the Intertropical Convergence Zone (ITCZ) (Lelieveld et al., 2001). Further, a drastic decrease in mean clear-sky solar radiative heating has also been observed in 1998- and 1999-winter at the Indian Ocean surface (Satheesh and Ramanathan, 2000) as a consequence of high loading of aerosols in this region.

Novakov et al. (2000) reported that fossil fuel combustion and biomass burning would contribute about $80 \%$ and $21 \%$ of carbonaceous aerosols over the tropical Indian Ocean, respectively. On the other hand, Guazzotti et al. (2003) found that the predominance of submicron, chemically mixed particles contain abundant carbon and potassium $\left(\mathrm{K}^{+}\right.$, a tracer for biofuel/biomass burning; Andreae and Merlet, 2001; Chow et al., 1994), implying a biomass burning origin of aerosols in this region. Recently, the relative contributions of fossil fuel combustion, open biomass burning and biofuel combustion to $\mathrm{BC}$ in India were estimated to be $25 \%, 33 \%$, and $42 \%$, respectively, whereas those to $\mathrm{OC}$ were to be $13 \%, 43 \%$, and $44 \%$, respectively (Venkataraman et al., 2005). Stone et al. (2010) also estimated small contribution from diesel combustion (4\%) and large contribution from biomass burning $(21 \%)$ to OC in the Himalayas.

However, chemical compositions of carbonaceous aerosols have rarely been studied in South Asia (Ram et al., 2008 and references therein) and no measurements of carbonaceous components have been reported from southern part of the Indian subcontinent, although BC was studied by using optical methods (Babu and Moorthy, 2002; Babu et al., 2002; Latha and Badrinath, 2003). Further, the studies on inorganic aerosols are also sparse in southern India (Khemani et al., 1982; Mouli et al., 2006), although they have been better documented in South and Southeast Asia (Ali-Mohamed, 1991; Negi et al., 1987; Parmar et al., 2001; Sharma and Patil, 1992).

In order to clarify chemical characteristics of the tropical aerosols in Indian region and specify their sources, we stud-

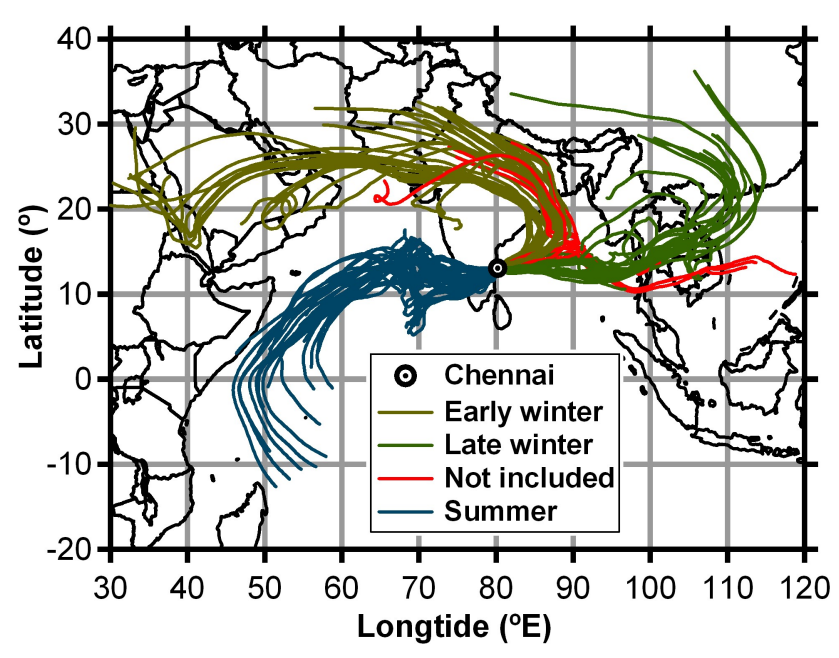

Fig. 1. A map of South and Southeast Asia with sampling site, Chennai $\left(13.04^{\circ} \mathrm{N} ; 80.17^{\circ} \mathrm{E}\right)$, India together with plots of 10-day backward air mass trajectories arriving at an altitude of $500 \mathrm{~m}$ over Chennai in winter (23 January to 6 February) and summer (22-31 May), 2007 showing three major pathways reflecting early winter, late winter and summer.

ied the atmospheric aerosol $\left(\mathrm{PM}_{10}\right)$ samples collected from Chennai, India in winter and summer, 2007 for carbonaceous (EC and OC) and water-soluble ionic components. Here, we discuss the contribution of biofuel/biomass burning and secondary production of carbonaceous aerosols during long-range transport from distant source regions in South and Southeast Asia based on mass concentration ratios and linear relations of selected ionic species, EC, OC and organic marker species (levoglucosan) together with backward air mass trajectory analyses. The results of carbonaceous components of this study would become as baseline data for southern part of the Indian subcontinent. Water-soluble organic species including dicarboxylic acids, ketoacids and $\alpha$-dicarbonyls in the Chennai aerosol samples have been reported elsewhere (Pavuluri et al., 2010a).

\section{Experimental}

\subsection{Aerosol sampling}

The tropical aerosol $\left(\mathrm{PM}_{10}\right)$ samples were collected in a mega-city, Chennai $\left(13.04^{\circ} \mathrm{N} ; 80.17^{\circ} \mathrm{E}\right)$ located on the south east coast of India (see Fig. 1). The geographical features of sampling site were described elsewhere (Pavuluri et al., 2010a). In Chennai region, winds follow a diurnal pattern due to land/sea breeze circulation (Srinivas et al., 2006, 2007) that may cause significant diurnal changes in chemical composition (e.g. WSOC/OC ratios) of atmospheric aerosols. In-situ photochemical production of WSOC may cause to enhance the WSOC/OC ratios in daytime than nighttime because the onset of sea breeze develops 
the thermal internal boundary layer (TIBL) below the atmospheric boundary layer (ABL) that restricts the vertical distribution, whereas in nighttime, the TIBL disappears and the $\mathrm{ABL}$ moves down by the onset of land breeze that reduces the influence of WSOC produced by in-situ secondary processes through vertical distribution of pollutants. Further the origin of air masses; marine in daytime and inland in nighttime, could also influence the chemical composition of the atmospheric aerosols at Chennai.

Sampling was performed on day- (approximately 06:0018:00 LT) and night-time (18:00-06:00 LT) basis, in winter (23 January to 6 February, $n=29$ ) and summer (2231 May, $n=20$ ), 2007 on the rooftop of the Mechanical Sciences building ( $\sim 18 \mathrm{~m}$ above the ground level), Indian Institute of Technology Madras (IITM), Chennai using a high volume air sampler (Envirotech APM 460 DX, India) and pre-combusted $\left(450^{\circ} \mathrm{C}, 4 \mathrm{~h}\right)$ quartz fiber filters (Pallflex 2500QAT-UP, $20 \times 25 \mathrm{~cm}$ ). The sample filter was placed in a pre-heated glass jar with a Teflon-lined screw cap before and after sampling. After sampling, the filters were stored in darkness at $-20^{\circ} \mathrm{C}$ prior to analysis.

\subsection{Chemical analyses}

\subsubsection{Carbonaceous components}

EC and OC were determined using OC/EC Analyzer (Sunset Laboratory Inc., USA) following Interagency Monitoring Protected Visual Environments (IMPROVE) thermal/optical evolution protocol and assuming carbonate carbon to be negligible. A filter disc $(1.4 \mathrm{~cm}$ in diameter) was placed in a quartz boat inside the thermal desorption chamber of the analyzer and then stepwise heating was applied in a He flow at first and then after the initial ramp, He gas was switched to $\mathrm{He} / \mathrm{O}_{2}$ mixture (Wang et al., 2005). The evolved $\mathrm{CO}_{2}$ at each temperature step was measured directly by a nondispersive infrared (NDIR) detector system and the transmittance of light (red $660 \mathrm{~nm}$ ) through the filter punch was used for setting up OC/EC split point and thereby OC correction. The analytical errors in duplicate analysis were within $1.2 \%$ for $\mathrm{OC}$ and $1.7 \%$ for EC. The detection limit for both EC and $\mathrm{OC}$ are $0.2 \mu \mathrm{g} \mathrm{cm}^{-2}$.

Water-soluble organic carbon (WSOC) was determined as described in Wang et al. (2005). Briefly, an aliquot of filter (3 discs with $2 \mathrm{~cm}$ in diameter) was extracted with $15 \mathrm{ml}$ organic free Milli-Q water under ultrasonication for $20 \mathrm{~min}$. The extracts were then filtered using a syringe filter (Millex$\mathrm{GV}, 0.22 \mu \mathrm{m}$, Millipore) and then WSOC was measured using TOC analyzer (Shimadzu 5000A). The analytical error in duplicate analysis was within $8 \%$ (Pavuluri et al., 2010a).

The sum of EC and OC was considered as total carbon (TC). The difference between OC and WSOC was considered as water-insoluble OC (WIOC).

\subsubsection{Water-soluble ionic species}

The water-soluble ionic species (methanesulfonate: $\mathrm{MSA}^{-}$ $\left(\mathrm{CH}_{3} \mathrm{SO}_{3}^{-}\right), \mathrm{Cl}^{-}, \mathrm{NO}_{3}^{-}, \mathrm{SO}_{4}^{2-}, \mathrm{Na}^{+}, \mathrm{NH}_{4}^{+}, \mathrm{K}^{+}, \mathrm{Mg}^{2+}$ and $\mathrm{Ca}^{2+}$ ) were measured using a part of extracts prepared for WSOC by ion chromatograph (761 Compact IC, Metrohm, Switzerland). A mixture of $1.8 \mathrm{mM} \mathrm{Na}_{2} \mathrm{CO}_{3}$ and $17 \mathrm{mM}$ $\mathrm{NaHCO}_{3}$ and $40 \mathrm{mM} \mathrm{H}_{2} \mathrm{SO}_{4}$ were used as eluent at a flow rate of $1.2 \mathrm{~mL} \mathrm{~min}^{-1}$ and suppressor for anion measurement, respectively. The $4 \mathrm{mM} \mathrm{H}_{3} \mathrm{PO}_{4}$ was used as eluent at a flow rate of $1.0 \mathrm{~mL} \mathrm{~min}^{-1}$ for cation measurement. A calibration curve was evaluated for each sequence by the analyses of a set of authentic standards and the analytical errors in duplicate analysis were within $6 \%$ (Pavuluri et al., 2010b). The nss- $\mathrm{SO}_{4}^{2-}$, nss- $\mathrm{K}^{+}$and nss-Ca ${ }^{2+}$ were calculated using $\mathrm{Na}^{+}$ as a reference tracer for sea-salt correction.

All the concentrations of carbonaceous and ionic components reported here are corrected for field blanks. The adsorption of organic gases on to the filter is considered to be negligible and no correction is made for the concentrations of carbonaceous components reported here.

\subsection{Estimated organic matter (OM) and secondary organic carbon (SOC)}

Atmospheric concentrations of $\mathrm{OM}$ are normally estimated by multiplying the measured OC concentrations with a conversion factor (1.6 \pm 0.2 ; Turpin and Lim, 2001). In this work, OM was estimated by using a factor of 1.7 , as higher ratios are possible for aerosols influenced by anthropogenic emissions (Turpin and Lim, 2001). In fact, Mayol-Bracero et al. (2002) used a factor of 1.7 for organic aerosols over the Indian Ocean, which were considered to be transported from the South and Southeast Asian countries.

Primary OC (POC) and SOC were estimated following the EC-tracer method (Castro et al., 1999; Turpin and Huntzicker, 1995; Yu et al., 2004). EC is a good tracer of primary combustion-generated carbon. Primary OC/EC ratio is assumed to be relatively constant for a given area, season and local meteorology because EC and POC typically have the same sources. Hence, the minimum value of OC/EC ratios can be used to estimate the amount of SOC in the atmospheric aerosol for a specific region of interest (Castro et al., 1999) although it involves some degree of uncertainty.

In this work, we assume the following equations,

$$
\begin{aligned}
& {[\mathrm{POC}]=[\mathrm{OC} / \mathrm{EC}]_{\min } \times[\mathrm{EC}]+c} \\
& {[\mathrm{SOC}]=[\mathrm{OC}]_{\text {meas }}-[\mathrm{POC}]}
\end{aligned}
$$

where $[\mathrm{OC} / \mathrm{EC}]_{\min }$ is the minimum $\mathrm{OC} / \mathrm{EC}$ ratio observed during the sampling period, $c$ is a parameter to account for non-combustion sources contributing to the POC, and $[\mathrm{OC}]_{\text {meas }}$ is the measured OC concentration. Here, minimum OC/EC ratios of 0.7 and 3.35 were used for winter and summer, respectively, which are reasonable since the OC/EC 
Table 1. Statistical summary of carbonaceous and ionic components $\left(\mu \mathrm{g} \mathrm{m}^{-3}\right)$ in the tropical Indian aerosol $\left(\mathrm{PM}_{10}\right)$ samples collected on day- and night-time bases in winter (23 January to 6 February) and summer (22-31 May) 2007 from Chennai, India.

\begin{tabular}{|c|c|c|c|c|c|c|c|c|c|c|c|c|}
\hline \multirow[t]{3}{*}{ Components } & \multicolumn{6}{|c|}{ Winter } & \multicolumn{6}{|c|}{ Summer } \\
\hline & \multicolumn{3}{|c|}{ Daytime } & \multicolumn{3}{|c|}{ Nighttime } & \multicolumn{3}{|c|}{ Daytime } & \multicolumn{3}{|c|}{ Nighttime } \\
\hline & Range & Ave./Med. ${ }^{\mathrm{a}}$ & $\mathrm{SD}^{\mathrm{b}}$ & Range & Ave./Med. & SD & Range & Ave./Med. & SD & Range & Ave./Med. & SD \\
\hline \multicolumn{13}{|c|}{ Carbonaceous components } \\
\hline EC & $3.8-7.5$ & $5.8 / 5.7$ & 1.3 & $2.4-14.0$ & $7.1 / 6.8$ & 3.5 & $1.1-2.5$ & $1.7 / 1.7$ & 0.4 & $1.1-1.9$ & $1.5 / 1.6$ & 0.3 \\
\hline $\mathrm{OC}^{\mathrm{c}}$ & $4.4-13.9$ & $8.5 / 7.4$ & 3.2 & $3.2-15.6$ & $9.8 / 10.6$ & 4.1 & $6.4-9.8$ & $8.4 / 8.5$ & 1.2 & $4.2-17.6$ & $11.0 / 10.9$ & 4.8 \\
\hline WSOC $^{\mathrm{d}}$ & $2.6-7.0$ & $4.2 / 4.0$ & 1.4 & $1.7-5.1$ & $3.3 / 3.1$ & 1.0 & $3.4-6.0$ & $4.4 / 4.4$ & 0.8 & $2.2-4.8$ & $3.8 / 3.8$ & 0.9 \\
\hline WIOC & $1.6-8.0$ & $4.3 / 3.0$ & 2.2 & $1.5-11.6$ & $6.5 / 5.8$ & 3.9 & $2.9-5.4$ & $3.9 / 3.9$ & 0.7 & $2.0-12.9$ & $7.3 / 6.8$ & 4.1 \\
\hline POC & $2.7-5.3$ & $4.1 / 4.0$ & 0.93 & $1.7-9.8$ & $5.0 / 4.8$ & 2.5 & $3.8-8.4$ & $5.7 / 5.7$ & 1.5 & $3.6-6.2$ & $5.2 / 5.4$ & 0.97 \\
\hline SOC & $0.0-9.2$ & $4.4 / 3.7$ & 2.9 & $0.84-8.9$ & $4.9 / 4.9$ & 2.7 & $0.51-3.8$ & $2.7 / 2.9$ & 0.9 & $0.0-13.1$ & $5.8 / 5.5$ & 4.8 \\
\hline \multicolumn{13}{|c|}{ Ionic components } \\
\hline $\mathrm{MSA}^{-}$ & $0.18-0.48$ & $0.30 / 0.30$ & 0.09 & $0.13-0.64$ & $0.30 / 0.22$ & 0.17 & $0.07-0.16$ & $0.11 / 0.10$ & 0.04 & $0.04-0.18$ & $0.08 / 0.09$ & 0.04 \\
\hline $\mathrm{Cl}^{-}$ & $0.12-2.0$ & $0.63 / 0.45$ & 0.56 & $0.32-3.1$ & $1.6 / 1.7$ & 0.81 & $0.05-0.35$ & $0.15 / 0.12$ & 0.10 & $0.06-0.70$ & $0.26 / 0.22$ & 0.21 \\
\hline $\mathrm{NO}_{3}^{-}$ & $0.22-1.26$ & $0.66 / 0.66$ & 0.27 & $0.46-3.1$ & $1.1 / 0.95$ & 0.67 & $0.39-1.0$ & $0.58 / 0.50$ & 0.21 & $0.21-1.06$ & $0.65 / 0.58$ & 0.29 \\
\hline $\mathrm{SO}_{4}^{2-}$ & $6.9-15.3$ & $9.6 / 8.8$ & 2.3 & $4.2-11.9$ & $7.8 / 8.2$ & 2.4 & $1.5-11.8$ & $4.8 / 4.8$ & 3.1 & $0.96-8.9$ & $3.3 / 2.6$ & 2.1 \\
\hline $\mathrm{Na}^{+}$ & $0.18-1.40$ & $0.51 / 0.42$ & 0.32 & $0.18-0.66$ & $0.38 / 0.38$ & 0.16 & $0.25-0.76$ & $0.46 / 0.46$ & 0.15 & $0.13-0.93$ & $0.48 / 0.47$ & 0.20 \\
\hline $\mathrm{NH}_{4}^{+}$ & $0.38-2.79$ & $1.82 / 1.96$ & 0.66 & $0.29-3.9$ & $2.3 / 2.5$ & 1.2 & $0.48-3.5$ & $1.4 / 1.3$ & 0.97 & $0.34-3.1$ & $1.1 / 0.93$ & 0.76 \\
\hline $\mathrm{K}^{+{ }^{+}}$ & $0.44-1.1$ & $0.80 / 0.78$ & 0.20 & $0.49-1.0$ & $0.77 / 0.79$ & 0.20 & $0.28-0.62$ & $0.40 / 0.38$ & 0.11 & $0.14-0.46$ & $0.31 / 0.32$ & 0.09 \\
\hline $\mathrm{Mg}^{2+}$ & $0.04-0.82$ & $0.24 / 0.18$ & 0.22 & $0.01-0.34$ & $0.14 / 0.13$ & 0.11 & $0.03-0.09$ & $0.05 / 0.04$ & 0.03 & $0.01-0.08$ & $0.04 / 0.04$ & 0.02 \\
\hline $\mathrm{Ca}^{2+}$ & $0.12-2.0$ & $0.61 / 0.39$ & 0.52 & $0.07-0.55$ & $0.28 / 0.23$ & 0.17 & $0.15-0.80$ & $0.37 / 0.33$ & 0.19 & $0.08-0.29$ & $0.14 / 0.13$ & 0.06 \\
\hline nss-SO ${ }_{4}^{2-}$ & $6.8-15.1$ & $9.5 / 8.7$ & 2.3 & $4.1-11.8$ & 7.8/8.1 & 2.4 & $1.4-11.6$ & $4.7 / 4.7$ & 3.1 & $0.92-8.7$ & $3.2 / 2.5$ & 2.1 \\
\hline nss- $\mathrm{K}^{+}$ & $0.42-1.08$ & $0.78 / 0.76$ & 0.20 & $0.47-1.02$ & $0.75 / 0.78$ & 0.20 & $0.26-0.60$ & $0.38 / 0.36$ & 0.11 & $0.14-0.43$ & $0.29 / 0.30$ & 0.09 \\
\hline nss-Ca ${ }^{2+}$ & $0.10-1.9$ & $0.60 / 0.38$ & 0.50 & $0.06-0.53$ & $0.27 / 0.22$ & 0.16 & $0.13-0.78$ & $0.36 / 0.31$ & 0.19 & $0.08-0.25$ & $0.12 / 0.11$ & 0.05 \\
\hline
\end{tabular}

${ }^{\mathrm{a}}$ Ave. $=$ average; Med. $=$ Median; ${ }^{\mathrm{b}} \mathrm{SD}=$ Standard Deviation; ${ }^{\mathrm{c}}$ OC data from Fu et al. (2010); ${ }^{\mathrm{d}}$ WSOC data from Pavuluri et al. (2010a)

ratio depends on the type of biofuel/biomass and burn rate (Stone et al., 2010), and the POC contribution from noncombustion sources was assumed to be negligible.

The possible uncertainties in SOC estimation were checked using the lowest $10 \%$ of $\mathrm{OC} / \mathrm{EC}$ values as primary $\mathrm{OC} / \mathrm{EC}$ ratio instead of the minimum OC/EC ratio across the entire sampling period. The lowest $10 \% \mathrm{OC} / \mathrm{EC}$ ratios are most likely controlled by primary carbonaceous aerosol (Lim et al., 2002). The SOC values estimated using the lowest $10 \%$ OC/EC value were found to be always lower than that estimated using the minimum $\mathrm{OC} / \mathrm{EC}$ ratio. The uncertainty for the average SOC was $20 \%$ in winter and $24 \%$ in summer and $18 \%, 22 \%, 43 \%$ and $16 \%$ in winter-day, winter-night, summer-day and summer-night, respectively. In fact, these uncertainties are comparable to that $( \pm 28 \%)$ reported in other study, in which the primary OC/EC value was estimated from linear regression of the datasets of the primary-dominated OC-EC concentrations (Miyazaki et al., 2006). Further the average contribution of SOC, estimated using the minimum OC/EC ratio, to OC was $47 \%$ in winter and $38 \%$ in summer, which are also comparable to that (ave. $46 \%$ ) reported in the literature (Lim et al., 2002).

The average SOC estimated using the lowest $10 \%$ of $\mathrm{OC} / \mathrm{EC}$ values across the entire year (winter and summer data together) was higher by a factor of 2.7 than that estimated using the lowest $10 \%$ OC/EC values across only the season, contributing $82 \%$ to OC, in summer although it was almost same in both the cases in winter. Further the average SOC estimated using the lowest $10 \%$ OC/EC values across each category of seasons within winter; early- and late-winter (see Sect. 2.5 for details on classification of seasons based on source region) and day and night, did not show any significant variation. Thus, this sensitivity analysis supports that the SOC estimated using minimum OC/EC ratio as the primary $\mathrm{OC} / \mathrm{EC}$ in winter and summer in this study is reasonable.

\subsection{Meteorology}

According to meteorological station of IITM (sampling site), the ambient temperature and relative humidity were varied from 14.2 to $34.9^{\circ} \mathrm{C}$ (ave. $23^{\circ} \mathrm{C}$ ) and $38 \%$ to $89 \%$ (ave. $68 \%$ ) in winter, whereas in summer their ranges were 28.3 $41^{\circ} \mathrm{C}$ (ave. $32^{\circ} \mathrm{C}$ ) and $31-81 \%$ (ave. $60 \%$ ), respectively. No rainfall was observed during the campaigns. Due to a strong land/sea thermal gradient, a clear diurnal oscillation was observed in wind speed and wind direction (Pavuluri et al., 2010a) but such a wind contrast decreases with height and disappears above $1 \mathrm{~km}$ (Srinivas et al., 2006).

\subsection{Backward air mass trajectories}

Ten-day backward air mass trajectories that arrive in Chennai at an altitude of $500 \mathrm{~m}$ for every $6 \mathrm{~h}$ were computed 
Table 2. Concentrations of EC and OC and mass ratios of OC to EC and EC to TC ${ }^{\mathrm{a}}$ in atmospheric aerosols from different locations in South Asia.

\begin{tabular}{|c|c|c|c|c|c|c|c|}
\hline \multirow[t]{2}{*}{ Location } & \multirow[t]{2}{*}{ Sampling period } & \multirow[t]{2}{*}{ Size } & \multicolumn{2}{|c|}{ Concentrations $\left(\mu \mathrm{g} \mathrm{m}^{-3}\right)$} & \multicolumn{2}{|c|}{ Concentration ratios } & \multirow[t]{2}{*}{ Reference } \\
\hline & & & $\mathrm{EC}$ & $\mathrm{OC}$ & $\mathrm{OC} / \mathrm{EC}$ & $\mathrm{EC} / \mathrm{TC}$ & \\
\hline Chennai, India & January-February (winter) 2007 & $\mathrm{PM}_{10}$ & $6.5 \pm 2.7$ & $9.1 \pm 3.7$ & $1.5 \pm 0.47$ & $0.42 \pm 0.08$ & This study \\
\hline Chennai, India & May (summer) 2007 & $\mathrm{PM}_{10}$ & $1.6 \pm 0.37$ & $9.7 \pm 3.7$ & $6.2 \pm 3.0$ & $0.15 \pm 0.04$ & This study \\
\hline Hisar, India & December 2004 & TSP & $3.8 \pm 1.4$ & $33.0 \pm 17.9$ & $8.47 \pm 2.19$ & $\mathrm{NA}^{\mathrm{b}}$ & Rengarajan et al. (2007) \\
\hline Manora Peak, India & December 2004 & TSP & $0.89 \pm 0.33$ & $4.9 \pm 1.3$ & $5.96 \pm 1.92$ & NA & Rengarajan et al. (2007) \\
\hline Manora Peak, India & February 2005-November 2006 & TSP & 1.1 & 8.7 & $8.4 \pm 2.8$ & NA & Ram et al. (2008) \\
\hline Mt. Abu, India & May 2005-February 2006 & TSP & 0.5 & 3.7 & $6.1 \pm 2.0$ & NA & Ram et al. (2008) \\
\hline Mumbai, India & January-February 1999 & $\mathrm{PM}_{10}$ & $12.4 \pm 5.1$ & $37.3 \pm 10.5$ & $3.1 \pm 0.5$ & NA & Venkataraman et al. (2002) \\
\hline Kanpur, India & January 2007-March 2008 & $\mathrm{PM}_{10}$ & $3.8 \pm 2.3$ & $25.8 \pm 16.1$ & $7.4 \pm 3.5$ & NA & Ram et al. (2010) \\
\hline Kathmandu valley, Nepal & February-May 1999, 2000 & $\mathrm{PM}_{10}$ & $1.5 \pm 0.9$ & $14.4 \pm 15.6$ & 9.6 & NA & Carrico et al. (2003) \\
\hline Himalaya, Nepal & February-May 1999, 2000 & $\mathrm{PM}_{10}$ & $0.48 \pm 0.38$ & $3.4 \pm 4.2$ & 7.1 & NA & Carrico et al. (2003) \\
\hline Godavari, Nepal & January-December, 2006 & $\mathrm{PM}_{2.5}$ & $1.0 \pm 0.8$ & $4.8 \pm 4.4$ & 4.8 & NA & Stone et al. (2010) \\
\hline Dhaka, Bangladesh & March-April 2001 & TSP & 22.0 & 45.7 & 2.08 & 0.32 & Salam et al. (2003) \\
\hline Lahore, Pakistan & September 1992-October 1993 & TSP & $17.6 \pm 10.2$ & $76.9 \pm 39.1$ & 4.37 & NA & Smith et al. (1996) \\
\hline Bay of Bengal & March-April 2006 & TSP & 0.4 & 1.9 & 7.4 & NA & Sudheer and Sarin (2008) \\
\hline Indian Ocean & February-March 1999 & $\mathrm{PM}_{2.5}$ & $2.5 \pm 1.4$ & $3.4 \pm 2.0$ & $1.36 \pm 1.1$ & $0.42 \pm 0.09$ & Mayol-Bracero et al (2002) \\
\hline
\end{tabular}

${ }^{\mathrm{a}} \mathrm{EC}=$ Elemental carbon; $\mathrm{OC}=$ Organic carbon; $\mathrm{TC}=\mathrm{EC}+\mathrm{OC},{ }^{\mathrm{b}} \mathrm{NA}=$ Not Available.

using Hybrid Single Particle Lagrangian Integrated Trajectory (HYSPLIT) model of the National Oceanic and Atmospheric Administration (NOAA) (http://www.ready.noaa. gov./ready/open/hysplit4.html). The obtained plots showed three major transport pathways with three different source regions during the campaigns (see Fig. 1). In winter (23 January to 6 February), the air masses that arrived in Chennai originated from the Middle East and/or the Indian mainland (ME/IN) in January and Southeast Asia (SEA) in February passing over the Bay of Bengal, except for few cases. Based on these trajectories, winter is further classified into two seasonal categories; early- (23-28 January) and late-winter (29 January to 6 February). However, the trajectories of 31 January (night) and 1 February fall in the category of early winter. Meanwhile, the results of 29 January (day), 30 January (night), 31 January (day), and 2 February (day) were not included in either categories and handled as such, because their air masses originated from mixed regions. In summer (22-31 May), the air masses originated from the Arabian Sea and/or the Indian Ocean (AS/IO) passing over southern part of the Indian subcontinent.

\section{Results and discussion}

\subsection{Characteristics and temporal variations}

\subsubsection{Carbonaceous components}

The statistical summaries of concentrations of carbonaceous components in the tropical Indian aerosol $\left(\mathrm{PM}_{10}\right)$ samples from Chennai are given in Table 1. Their temporal variations are shown in Fig. 2. Concentrations of EC and OC ranged from 1.1 to $14 \mu \mathrm{g} \mathrm{m}^{-3}$ (ave. $4.5 \mu \mathrm{g} \mathrm{m}^{-3}$ ) and 3.2 to
$17.6 \mu \mathrm{g} \mathrm{m}^{-3}$ (ave. $\left.9.4 \mu \mathrm{g} \mathrm{m}^{-3}\right)(n=49)$, respectively. $\mathrm{EC}$ concentrations showed higher values in winter than summer (see Table 2). But OC did not show significant difference between winter and summer (see Table 2). It is also of worth to note that $\mathrm{OC}$ was found to be the most abundant in the combined fraction of carbonaceous and ionic components of $\mathrm{PM}_{10}$. On the other hand, WSOC and WIOC concentration ranges were $1.7-7 \mu \mathrm{g} \mathrm{m}^{-3}$ (ave. $3.9 \mu \mathrm{g} \mathrm{m}^{-3}$ ) and 1.5$12.9 \mu \mathrm{g} \mathrm{m}^{-3}$ (ave. $\left.5.5 \mu \mathrm{g} \mathrm{m}^{-3}\right)(n=49)$, respectively. On average, both WSOC and WIOC did not show significant variation between winter $\left(3.8 \pm 1.3 \mu \mathrm{g} \mathrm{m}^{-3}, 5.4 \pm 3.3 \mu \mathrm{g} \mathrm{m}^{-3}\right.$, respectively) and summer $\left(4.1 \pm 0.9 \mu \mathrm{g} \mathrm{m}^{-3}, 5.6 \pm 3.3 \mu \mathrm{g} \mathrm{m}^{-3}\right.$, respectively). Similarly, SOC in winter $\left(4.6 \pm 2.8 \mu \mathrm{g} \mathrm{m}^{-3}\right)$ was also comparable to that in summer $\left(4.3 \pm 3.8 \mu \mathrm{g} \mathrm{m}^{-3}\right)$ but POC was little lower in winter $\left(4.5 \pm 1.9 \mu \mathrm{g} \mathrm{m}^{-3}\right)$ than summer $\left(5.4 \pm 2.8 \mu \mathrm{g} \mathrm{m}^{-3}\right)$. However, all the components, except EC in most of summer samples, showed a clear diurnal variation (see Table 1; Fig. 2; Sect. 3.4).

Higher concentrations of EC suggest that contributions from anthropogenic sources are larger in winter than in summer. Comparable concentrations of OC between summer and winter suggest that the organic aerosols have an additional source(s) (e.g. biogenic emissions) in summer because the intensity of secondary production may be equally significant in both the seasons as the prevailing solar radiations and temperatures over the region are high enough to promote photochemical processes. Conversely the average POC and SOC were comparable in both winter and summer but WIOC was higher than WSOC in both the seasons, indicating that part of WIOC was secondary. Further the differences in type of anthropogenic sources, particularly biofuel/biomass burning, might have also influenced the concentrations of EC and OC seasonally. The OC/EC ratios in particulates show a broad 


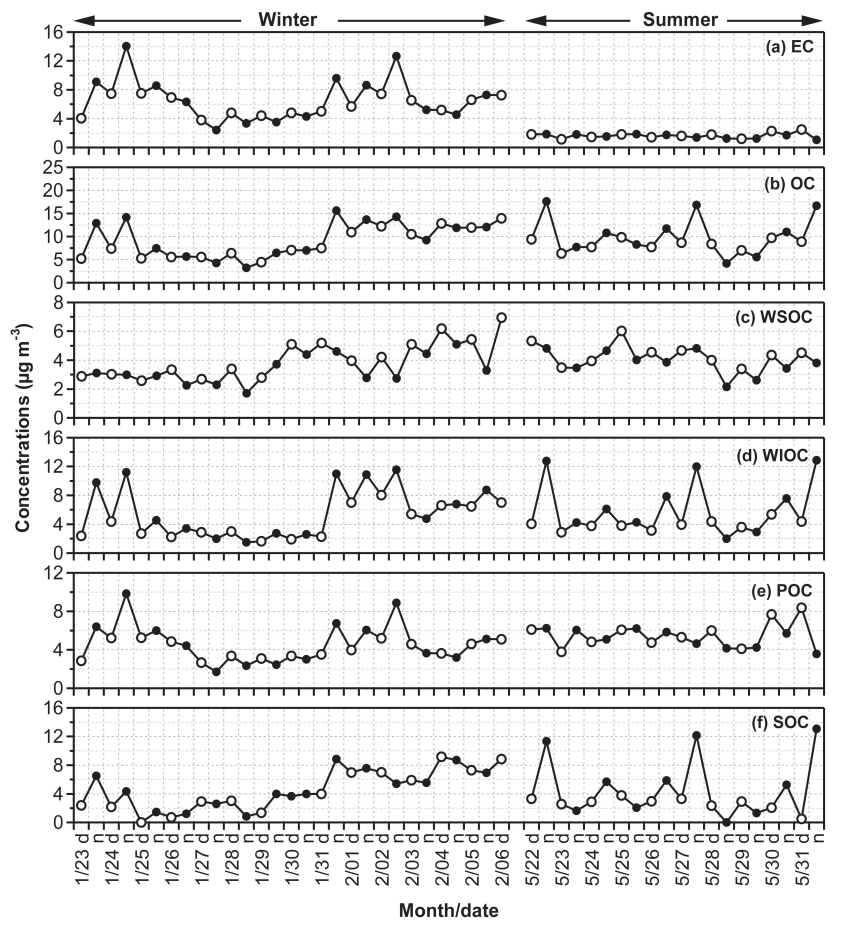

Fig. 2. Temporal variations of carbonaceous components in the tropical Indian aerosol $\left(\mathrm{PM}_{10}\right)$ samples $(n=49)$ collected on dayand night-time bases in winter (23 January to 6 February) and summer (22-31 May), 2007 from Chennai, India. Open and solid circles show the day- and night-time concentrations, respectively.

range (0.6-4.2) depending on type of biofuel and burn rate (see Sect. 3.4.1; Stone et al., 2010) and degree of secondary formation.

The seasonal distributions of EC and OC are consistent with the origins of air masses that arrived in Chennai; ME/IN and SEA in winter and AS/IO in summer. The air masses originated from ME/IN and SEA, where anthropogenic emissions including forest fires (Streets et al., 2003) are larger (Lelieveld et al., 2001), are enriched with EC and other pollutants. In contrast, the air masses originated from AS/IO passing over southern part of the Indian subcontinent, where the burning of cow-dung (Reddy and Venkataraman, 2002b) and livestock emissions (e.g. $\mathrm{CH}_{4}$; Garg et al., 2001) are significant, are enriched with OC rather EC. Marine biota and livestock emissions are the significant sources of OC. Cowdung combustion is known as more important source of OC than EC (Stone et al., 2010). High abundances of OC in $\mathrm{PM}_{10}$ also suggest that contributions from biospheric (biogenic/biomass burning) sources are higher than fossil fuel combustion in this region.

\subsubsection{Water-soluble ionic components}

The statistical summaries of water-soluble ionic species in the tropical Indian aerosol $\left(\mathrm{PM}_{10}\right)$ samples from Chennai

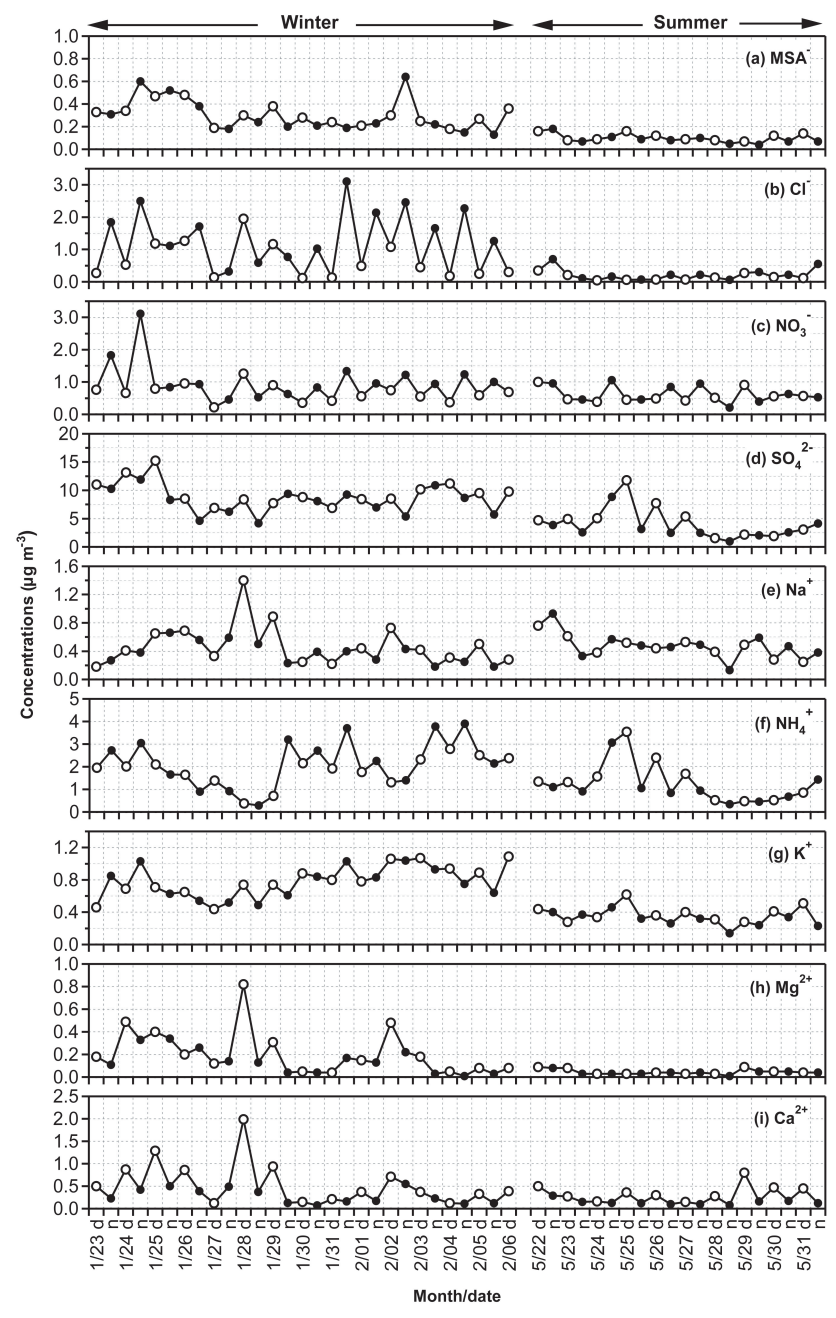

Fig. 3. Temporal variations of water-soluble ionic components in the tropical Indian aerosol $\left(\mathrm{PM}_{10}\right)$ samples $(n=49)$ collected on day- and night-time bases in winter (23 January to 6 February) and summer (22-31 May), 2007 from Chennai, India. Open and solid circles show the day- and night-time concentrations, respectively.

are given in Table 1. Their temporal variations are shown in Fig. 3. On average $(n=49), \mathrm{SO}_{4}^{2-}$ was found as the most abundant ionic species $\left(6.9 \mu \mathrm{g} \mathrm{m}^{-3}\right)$ followed by $\mathrm{NH}_{4}^{+}$ $\left(1.7 \mu \mathrm{g} \mathrm{m}^{-3}\right)$. They account for $57 \%$ and $15 \%$ of total ionic mass, respectively. $\mathrm{NO}_{3}^{-}\left(0.78 \mu \mathrm{g} \mathrm{m}^{-3}\right)$ was found as the third most abundant species followed by $\mathrm{Cl}^{-}\left(0.74 \mu \mathrm{g} \mathrm{m}^{-3}\right)$, $\mathrm{K}^{+}\left(0.61 \mu \mathrm{g} \mathrm{m}^{-3}\right), \mathrm{Na}^{+}\left(0.46 \mu \mathrm{g} \mathrm{m}^{-3}\right), \mathrm{Ca}^{2+}\left(0.37 \mu \mathrm{g} \mathrm{m}^{-3}\right)$, $\operatorname{MSA}^{-}\left(0.22 \mu \mathrm{g} \mathrm{m}^{-3}\right)$ and $\mathrm{Mg}^{2+}\left(0.13 \mu \mathrm{g} \mathrm{m}^{-3}\right)(n=49)$. The contributions of nss- $\mathrm{SO}_{4}^{2-}$, nss- $\mathrm{K}^{+}$and nss- $\mathrm{Ca}^{2+}$ to the total $\mathrm{SO}_{4}^{2-}, \mathrm{K}^{+}$and $\mathrm{Ca}^{2+}$ concentrations were on average $97.7 \%, 96.5 \%$ and $93 \%$ (range, $93-99.6 \%, 91-99.3 \%$ and $78-98.6 \%$ ), respectively, demonstrating the dominant contributions from anthropogenic sources compared to marine sources. Seasonal distributions of ionic species showed peak concentrations in wintertime (Fig. 3). The average 
concentrations of ionic species, except $\mathrm{NO}_{3}^{-}$and $\mathrm{Na}^{+}$, were 2 to 5 times higher in winter than in summer (Table 1). However, $\mathrm{NO}_{3}^{-}$showed a little higher average concentration in winter $\left(0.89 \mu \mathrm{g} \mathrm{m}^{-3}\right)$ than summer $\left(0.61 \mu \mathrm{g} \mathrm{m}^{-3}\right)$. Furthermore, most ionic species, except for $\mathrm{MSA}^{-}, \mathrm{Cl}^{-}, \mathrm{NO}_{3}^{-}$and $\mathrm{NH}_{4}^{+}$, showed a clear diurnal variation with daytime maxima (see Table 1; Fig. 3; Sect. 3.4).

High abundances of $\mathrm{SO}_{4}^{2-}$ in ionic mass of Chennai aerosols suggest that the contributions from fossil fuel combustion are higher than other sources, e.g., biomass burning. In contrast, its concentrations, which is twice higher in winter (ave. $8.8 \mu \mathrm{g} \mathrm{m}^{-3}$ ) compared to summer (ave. $4.1 \mu \mathrm{g} \mathrm{m}^{-3}$ ), together with the air mass trajectories (Fig. 1) demonstrate that the source strength and/or source type are different in each season because industrial emission of $\mathrm{SO}_{2}$ is significant not only in northern part of India but also in southern tip of India (Mayol-Bracero et al., 2002). On the other hand, average concentration of $\mathrm{NH}_{4}^{+}$that contributes from biomass burning as well as animal excreta (Olivier et al., 1998) was twice higher in winter $\left(2.1 \mu \mathrm{g} \mathrm{m}^{-3}\right)$ than in summer $\left(1.3 \mu \mathrm{g} \mathrm{m}^{-3}\right)$ whereas $\mathrm{NO}_{3}^{-}$that emits from fossil fuel combustion (Olivier et al., 1998) did not show significant seasonal variation (Table 1).

Furthermore, the average concentrations of $\mathrm{MSA}^{-}$and $\mathrm{Cl}^{-}$, which are generally considered to be of marine origin, were higher in winter $\left(0.3 \mu \mathrm{g} \mathrm{m}^{-3}\right.$ and $\left.1.1 \mu \mathrm{g} \mathrm{m}^{-3}\right)$ than in summer $\left(0.1 \mu \mathrm{g} \mathrm{m}^{-3}\right.$ and $\left.0.2 \mu \mathrm{g} \mathrm{m}^{-3}\right)$ by a factor of 3 and 5 , respectively, although the air masses that arrived in Chennai originated from oceanic region in summer and continental region in winter (Fig. 1). In fact, biomass burning produces dimethyl sulfide (DMS) (Meinardi et al., 2003), a precursor for $\mathrm{MSA}^{-}$(von Glasow and Crutzen, 2004), as well as $\mathrm{Cl}^{-}$(Keene et al., 2006; Watson et al., 2001; Yamasoe et al., 2000). Thus, the distributions of these signature ions suggest that biofuel/biomass burnings rather than fossil fuel combustion are significant sources in South and Southeast Asia.

\subsubsection{Ionic balance}

Average equivalent ratios of total cations $\left(\mathrm{Na}^{+}, \mathrm{NH}_{4}^{+}, \mathrm{K}^{+}\right.$, $\mathrm{Mg}^{2+}$ and $\left.\mathrm{Ca}^{2+}\right)$ to anions $\left(\mathrm{Cl}^{-}, \mathrm{NO}_{3}^{-}\right.$and $\left.\mathrm{SO}_{4}^{2-}\right)$ were 0.85 (range, 0.67-1.07) in winter and 1.21 (range, 1.01-1.58) in summer. The linear regression lines for total cations and anions are shown in Fig. 4 for day- and night-time samples in winter and summer. A significant cation deficiency was found in winter, probably due to the exclusion of $\mathrm{H}^{+}$, suggesting that the Chennai aerosols are more acidic in winter than summer. Ammonia is a dominant alkaline gas that neutralizes the acidic particles in the atmosphere. However, $\mathrm{NH}_{4}^{+} / \mathrm{SO}_{4}^{2-}$ equivalent ratios were only 0.63 in winter and 0.81 in summer. In fact, concentrations of dicarboxylic acids were higher (range, $351-1030 \mathrm{\mu g} \mathrm{m}^{-3}$ ) in winter than summer (range, 226-652 $\mu \mathrm{g} \mathrm{m}^{-3}$ ) (Pavuluri et al., 2010a). The low $\mathrm{NH}_{4}^{+} / \mathrm{SO}_{4}^{2-}$ equivalent ratios, particularly in winter, suggest that $\mathrm{NH}_{3}$ was insufficient to neutralize all $\mathrm{SO}_{2}$

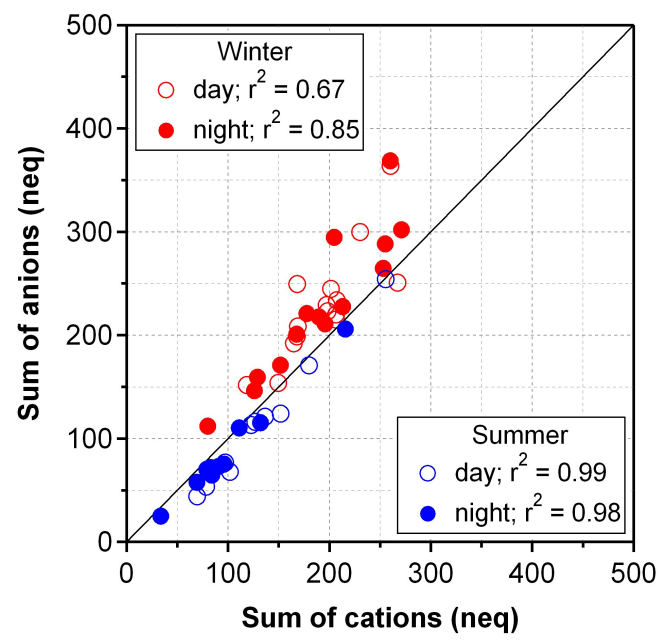

Fig. 4. Linear regression plots between sum of cation equivalents (neq) and anion equivalents (neq) in the tropical Indian aerosol $\left(\mathrm{PM}_{10}\right)$ samples collected on day- and night-time bases in (a) winter (23 January to 6 February) and (b) summer (22-31 May), 2007 from Chennai, India.

and hence $\mathrm{H}_{2} \mathrm{SO}_{4}$ and $\mathrm{NH}_{4} \mathrm{HSO}_{4}$ were present in addition to $\left(\mathrm{NH}_{4}\right)_{2} \mathrm{SO}_{4}, \mathrm{NH}_{4} \mathrm{NO}_{3}$ and $\mathrm{NH}_{4} \mathrm{Cl}$. The enhanced cation to anion and $\mathrm{NH}_{4}^{+} / \mathrm{SO}_{4}^{2-}$ ratios in summer suggest a plausible association of cations, including $\mathrm{NH}_{4}^{+}$, with organic acids. However, the association of acidic species with metals (such as $\mathrm{Mg}^{2+}$ and $\mathrm{Ca}^{2+}$ ) might be insiginificant as their concentrations were low in Chennai aerosols (Table 1).

\subsection{Comparison of $\mathrm{EC}$ and $\mathrm{OC}$ in Chennai with previous studies in South Asia}

Table 2 compares the concentrations of EC and $\mathrm{OC}$ and mass concentration ratios of OC to EC and EC to TC in Chennai aerosols together with those from different locations in South Asia including the Bay of Bengal and the Indian Ocean. In winter, the average concentration $\left(6.5 \mu \mathrm{g} \mathrm{m}^{-3}\right)$ of EC in Chennai is higher than those reported in Hisar, Manora Peak and over the Indian Ocean but lower than that reported in Mumbai (Table 2). In summer, EC concentration in Chennai is comparable to that reported in Kathmandu valley, higher than those reported in remote Himalayas and over the Bay of Bengal and lower than that reported in Dhaka (Table 2). In contrast, the average concentrations of OC in Chennai in both winter and summer are lower than that reported in Hisar in winter and in Kathmandu valley in summer (Table 2). These comparisons to other locations are similar to the case of EC (Table 2).

The major sources of carbonaceous aerosols in Kathmandu valley, remote Himalaya and Godavari are expected to be biofuel combustion (cow-dung cake, wood and agricultural waste) and biomass burning (Carrico et al., 2003; Stone et al., 2010). Similarly, the major contributions of 
carbonaceous aerosols in Hisar, Manora Peak and Mt. Abu as well as over the Bay of Bengal were attributed to be biomass burning (Ram et al., 2008; Rengarajan et al., 2007; Sudheer and Sarin, 2008). In contrast, fossil fuel combustion is expected to be the major source of EC and OC in mega-cities; Mumbai (Venkataraman et al., 2002), Dhaka (Salam et al., 2003) and Lahore (Smith et al., 1996). Further, emissions from fossil fuel combustion (60-80\%) and biomass burning $(20-40 \%)$ in South and Southeast Asia are considered as the sources of EC and OC over the Indian Ocean (Mayol-Bracero et al., 2002).

\subsection{Seasonal changes in mass fractions of EC, OM and ionic species in $\mathrm{PM}_{10}$ : role of source regions}

Distributions of mass fractions of EC, OM and ionic species in $\mathrm{PM}_{10}$ for three seasons; early winter, late winter and summer, as categorized by the source regions of air masses that arrived in Chennai during the campaigns (see Sect. 3.1 and Fig. 1), are given by box-and-whisker plots in Fig. 5. The mass fractions of $\mathrm{EC}, \mathrm{SO}_{4}^{2-}$ and $\mathrm{K}^{+}$were higher in late winter than early winter when the air masses originated from SEA and ME/IN, respectively (Fig. 1). They are lowest in summer when air masses arrived in Chennai from AS/IO (Fig. 1). Meanwhile, mass fractions of $\mathrm{OM}$ and $\mathrm{NH}_{4}^{+}$were higher in late winter than in summer and in early winter. However, $\mathrm{MSA}^{-}, \mathrm{Cl}^{-}$and $\mathrm{NO}_{3}^{-}$did not show any significant difference between early- and late-winter. In contrast, mass fractions of $\mathrm{Mg}^{2+}$ and $\mathrm{Ca}^{2+}$ were higher in early winter and $\mathrm{Na}^{+}$fraction was higher in summer.

It is well known that biomass burning including forest fires are commonly occurred in South and Southeast Asia but the amount of vegetation burned in Southeast Asia (331 Tg dry matter) are almost twice large compared to those of South Asia (178 Tg; Streets et al., 2003). Similarly, the consumption of bio-fuel, in particular cow-dung (Reddy and Venkataraman, 2002b), and livestock emissions (e.g. $\mathrm{CH}_{4}$; Garg et al., 2001) are higher in southern part of India than any other parts of the Indian subcontinent. Thus the origins of the air masses and their source strength should have played a vital role in changing the concentrations of carbonaceous and ionic components from season to season. These considerations also indicate that biomass burning is a significant source of EC, OC, $\mathrm{SO}_{4}^{2-}$ and $\mathrm{NH}_{4}^{+}$as well as $\mathrm{MSA}^{-}$, $\mathrm{Cl}^{-}$and $\mathrm{NO}_{3}^{-}$and the intensity of biomass burning emissions are higher in SEA than ME/IN. The less abundant EC mass fraction in summer is likely because biofuel combustion less contributes to EC compared to OC (Stone et al., 2010).
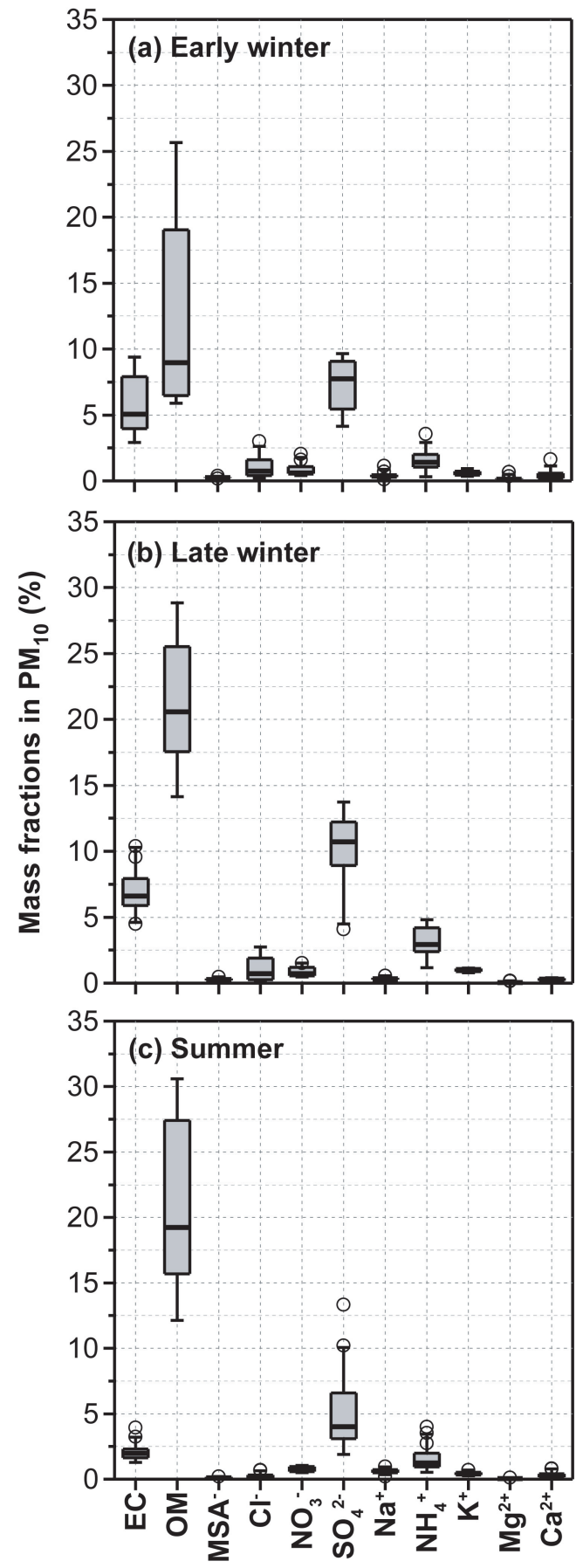

Fig. 5. Box-and whisker plots of mass fractions of EC, OM and ionic species $\left(\mathrm{MSA}^{-}, \mathrm{Cl}^{-}, \mathrm{NO}_{3}^{-}, \mathrm{SO}_{4}^{2-}, \mathrm{NH}_{4}^{+}, \mathrm{K}^{+}, \mathrm{Mg}^{2+}\right.$ and $\left.\mathrm{Ca}^{2+}\right)$ in the tropical Indian aerosol $\left(\mathrm{PM}_{10}\right)$ samples collected from Chennai, India in (a) early winter, (b) late winter and (c) summer, 2007. 


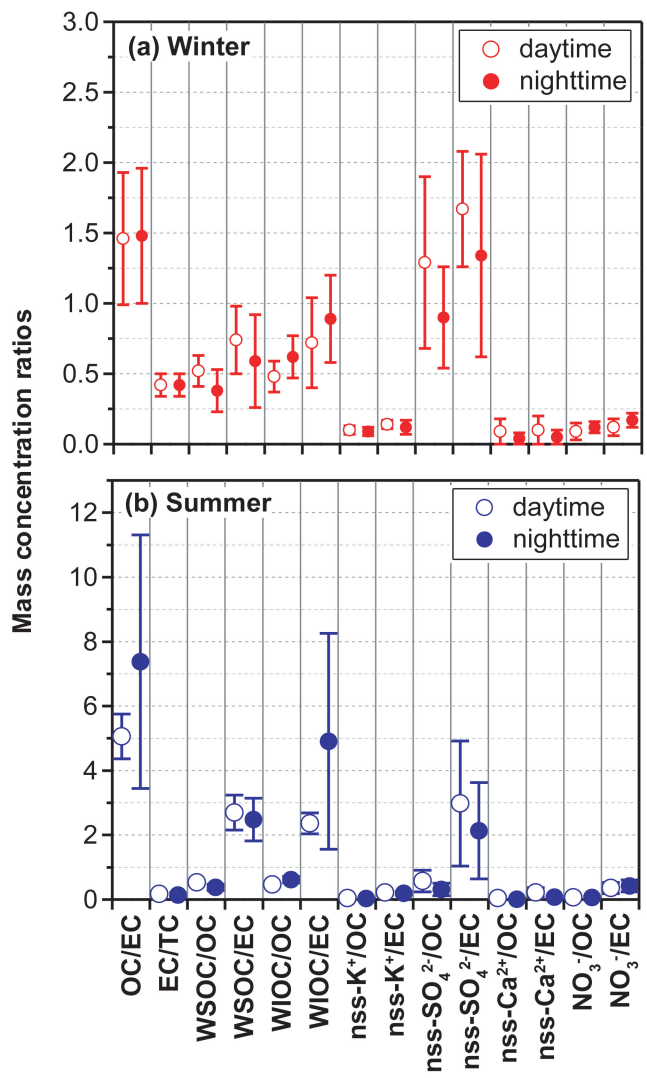

Fig. 6. Mass concentration ratios of selected components in the tropical Indian aerosol $\left(\mathrm{PM}_{10}\right)$ samples collected on day- and nighttime bases in (a) winter (23 January to 6 February) and (b) summer (22-31 May), 2007 from Chennai, India.

\subsection{Assessment of sources: biofuel/biomass burning and secondary production during long-range atmospheric transport}

\subsubsection{Mass concentration ratios of selected components}

Figure 6 shows the mass concentration ratios of selected components in Chennai aerosols. The mass concentration ratios of OC/EC were higher in summer than winter whereas $\mathrm{EC} / \mathrm{TC}$ were higher in winter than summer (Table 2). OC/EC ratios did not show day- to night-time variation in winter, whereas in summer, they were higher in nighttime than daytime (Fig. 6). It is apparent that the OC/EC ratios for most of the urban sites around the world fall in the range between 1.0 and 4.0 and the OC/EC ratios exceeding 2.0 have been used to indicate the important presence of secondary organic aerosols (Cao et al., 2003). On the other hand, it has been inferred that wood burning generally produces a small fraction of EC in TC, typically around $10 \%$ or less (Andreae and Merlet, 2001), whereas vehicular emissions especially from diesel engines contain a larger fraction (about $50 \%$ ) of EC in TC (Gillies et al., 2001).
OC/EC ratios in Chennai winter aerosols are similar to those reported over the Indian Ocean (Table 2) and comparable to those $(<4.0)$ reported for urban locations (Table 2; Cao et al., 2003). In addition, EC/TC ratios are also similar to those reported over the Indian Ocean (Table 2) and comparable to those (0.56) reported in road tunnel aerosols (Gillies et al., 2001). EC mass fraction in TC was also always higher than $10 \%$, a typical value for wood burning (Andreae and Merlet, 2001). These results and comparisons suggest that the contributions from fossil fuel combustion could be highly significant in winter. However, this is not necessarily the actual case.

The air masses that arrived in Chennai originated from ME/IN and SEA in winter (Fig. 1) where biofuel/biomass burning including forest fires are significant (Streets et al., 2003). EC emission from biomass burning depends on burn rate $\left(\mathrm{kg} \mathrm{h}^{-1}\right)$ and type of biomass (Habib et al., 2008; Stone et al., 2010) that can lead the OC/EC and EC/TC ratios to be comparable to those of fossil fuel combustion emissions. Habib et al. (2008) found a significant negative correlation $\left(r^{2}=0.5\right)$ between $\mathrm{EC} / \mathrm{PM}_{2.5}$ ratio and burn rate. Stone et al. (2010) reported extremely high EC/OC ratio (1.68) for mango wood burning at low burn rate compared to that $(0.24)$ at high burn rate. In fact, most of cooking energy in South and Southeast Asia come from biofuel (cow-dung, wood and agricultural waste) combustion, generally at low rate, that could contribute a larger amount of EC to the atmosphere. Interestingly, OC/EC ratios were higher and EC/TC ratios were lower in summer than winter, which is mainly driven by EC, although the air masses originated from AS/IO passed over southern part of the Indian subcontinent where anthropogenic emissions are significant, probably due to differences in types of sources (biofuel/biomass). In fact, consumption of cow-dung (Reddy and Venkataraman, 2002b) and live stock emissions (e.g. $\left.\mathrm{CH}_{4}\right)(\mathrm{Garg}$ et al., 2001) are higher in southern part of India than in other parts of India that may contribute negligible amount of EC. Further, the $\mathrm{OC} / \mathrm{EC}$ ratios, particularly in winter, are highly comparable to those reported in rural and mountain sites where the biofuel/biomass burning was expected as a major source(s) (Table 2).

On the other hand, nss- $\mathrm{K}^{+} / \mathrm{EC}$ and $\mathrm{nss}-\mathrm{K}^{+} / \mathrm{OC}$ ratios in Chennai aerosols ranged from 0.07 to $0.20(0.13 \pm 0.04)$ and 0.05 to $0.16(0.09 \pm 0.03)$ in winter and $0.11-0.33$ $(0.21 \pm 0.05)$ and $0.01-0.06(0.04 \pm 0.01)$ in summer, respectively. They did not show any significant diurnal variation (Fig. 6). These ratios are comparable to $\mathrm{K} / \mathrm{BC}$ and $\mathrm{K} / \mathrm{OC}$ ratios calculated from emission factors reported for tropical forest ( 0.44 and 0.06 , respectively) and the burning of agricultural residues (0.19 and 0.04, respectively; Andreae and Merelet, 2001). In addition, nss- $\mathrm{K}^{+} / \mathrm{EC}$ ratios in Chennai aerosols are much higher than that (ave. 0.05) reported in Christchurch, New Zealand, where wood and coal burning was considered as major sources of domestic energy (Wang et al., 2005). These comparisons clearly imply that 
biofuel/biomass burning are the major sources of Chennai aerosols.

The ratios of nss-SO ${ }_{4}^{2-} / \mathrm{EC}, \mathrm{nss}_{-} \mathrm{SO}_{4}^{2-} / \mathrm{OC}, \mathrm{nss}^{-\mathrm{Ca}^{2+} / \mathrm{EC}}$ and nss- $\mathrm{Ca}^{2+} / \mathrm{OC}$ in Chennai aerosols were found to be $1.5 \pm 0.59,1.1 \pm 0.53,0.14 \pm 0.06$ and $0.11 \pm 0.05$ in winter and $2.6 \pm 1.7,0.44 \pm 0.3,0.39 \pm 0.17$ and $0.07 \pm 0.02$ in summer, respectively, with daytime maxima in winter and summer (Fig. 6). These ratios are several times higher than those $(0.09,0.1,0.03$ and 0.03 , respectively) calculated from road tunnel aerosols (Gillies et al., 2001). Although $\mathrm{NO}_{3}^{-} / \mathrm{EC}$ and $\mathrm{NO}_{3}^{-} / \mathrm{OC}$ ratios $(0.14 \pm 0.06$ and $0.11 \pm 0.05)$ found in Chennai winter aerosols as well as $\mathrm{NO}_{3}^{-} / \mathrm{OC}$ ratios in Chennai summer aerosols are comparable to those $(0.08$ and 0.1 , respectively) obtained for road tunnel aerosols (Gillies et al., 2001), $\mathrm{NO}_{3}^{-} / \mathrm{EC}$ ratios $(0.39 \pm 1.7)$ in Chennai summer aerosols are quite different. These comparisons also suggest that the Chennai aerosols have been seriously influenced by biofuel/biomass burning rather than fossil fuel combustion. Hence, we presume that EC might have also been contributed from biomass burning at significant level. Recently, Gustafsson et al. (2009) found a much larger contribution (46 and $68 \%$ ) of different fractions of black carbon from biomass burning in South Asia based on radiocarbon analyses $\left(\Delta^{14} \mathrm{C}\right)$, which further confirms that our assumption is reasonable.

WSOC/OC ratios ranged from 0.19 to 0.73 (ave. 0.45) in winter and 0.23-0.61 (ave. 0.45) in summer. We found that the ratios are higher in daytime $(0.52$ and 0.53 in winter and summer, respectively) than nighttime ( 0.38 in both winter and summer) (Fig. 6). The WSOC/OC ratio has been proposed as a measure of photochemical processing or aging during long-range transport (Aggarwal and Kawamura, 2009; Yang et al., 2004). The higher WSOC/OC ratios found in Chennai aerosols suggest that they were subjected for photochemical processing during long-range atmospheric transport and thus the contribution from secondary production is also significant. On the other hand, diurnal variations of WSOC/EC ratios were not significant in both winter and summer, suggesting that local emissions of EC (and OC) as well as in-situ photochemical production of WSOC may also be significant to certain extent in daytime.

Furthermore, WSOC/OC ratios in Chennai aerosols are comparable to those found in other rural and some urban sites where the contributions from biogenic/biomass burning emissions and/or photochemical processing are significant. The ratios are higher than those reported in some other urban sites where the fossil fuel combustion emissions were expected to be significant. On average WSOC accounted for $66 \%$ (range, $38-72 \%$ ) in fine $\left(D_{p}<1.5 \mu \mathrm{m}\right)$ aerosols collected from a rural site that situated on a forest clearing on the Great Hungarian Plain (Kiss et al., 2002), and $44 \%$ (range, 23-69\%) in Sapporo aerosols (TSP), which were considered as photochemically aged (Aggarwal and Kawamura, 2008). At an urban site in Nanjing, China, WSOC contributed $30 \%$ of $\mathrm{OC}$ in $\mathrm{PM}_{2.5}$ in winter (Yang et al., 2005). Miyazaki et al. (2006) reported that the median WSOC/OC ratios in Tokyo by semicontinuous measurements were 0.19 in winter and 0.35 in summer and fall where fossil fuel combustion was expected as the major source.

In addition, WSOC/OC ratios in Chennai aerosols are highly comparable to those from Kanpur (range 0.21$0.7)$ and Hisar $(0.32 \pm 0.14)$, India where biomass burning and/or secondary production were expected to be the major source(s) (Ram et al., 2010). Further it is also interesting to note that the average (median) WSOC/OC ratios $(0.51$ (0.48)) reported for Kanpur in summer are little lower than in postmonsoon (0.54 (0.53)) (Ram et al., 2010), which indicate that the source type or source strength is more important in controlling WSOC/OC ratios seasonally rather than secondary production. Because the ambient temperatures are high in all seasons, photochemical oxidation of organics in the atmosphere may be significant in all seasons in this region. Thus these comparisons again indicate that the biofuel/biomass burning emissions as well as photochemical processing during long-range atmospheric transport are significant in South and Southeast Asia.

On average, WIOC/OC ratio was 0.55 in both winter and summer whereas WIOC/EC ratios were 0.8 and 3.6 in winter and summer, respectively, which driven by EC concentrations. Diurnal variations of WIOC/OC were significant in both winter and summer whereas WIOC/EC did not (Fig. 6). The higher WIOC/OC ratios in nighttime than daytime are opposite to that of WSOC/OC but the distributions of WIOC were similar to that of SOC. This suggests that the origin of WIOC and SOC may be similar and most of the SOC may be water-insoluble (Saxena and Hildemann, 1996). The WIOC/EC ratios in summer were higher by a factor about 3 than those (range, 0.9-1.31) reported in Tokyo by semicontinuous measurements, where fossil fuel combustion was expected as the major source (Miyazaki et al., 2006), suggesting that WIOC might be contributed from other source (biofuel/biomass burning) rather fossil fuel combustion. However, the WIOC/EC in Chennai winter aerosols $(0.8 \pm 0.32)$ were comparable to those reported in Tokyo (Miyazaki et al., 2006) that may be due to differences in emission factors of EC and OC depending on type of biomass and/or burn rate (Habib et al., 2008; Stone et al., 2010).

\subsubsection{Linear relations of EC and OC with $\mathrm{nss}^{+} \mathrm{K}^{+}$and levoglucosan}

We now examine the linear relations of EC and OC with marker species; nss- $\mathrm{K}^{+}$and levoglucosan, to determine the degree to which they are consistent with the source strength (biofuel/biomass burning) based on mass concentration ratios of selected compounds. $\mathrm{K}^{+}$and EC are significantly emitted from biomass burning (Andreae, 1983) but the former does not contribute from fossil fuel combustion and hence $\mathrm{K}^{+}$can be used as marker for biomass burning. 
Levoglucosan is also an excellent marker for biomass burning as it is produced by pyrolysis of cellulose during biomass burning. Scatter plots of EC and OC with nss- $\mathrm{K}^{+}$and levoglucosan are shown in Fig. 7. EC showed medium correlations $\left(r^{2} \leq 0.5\right)$ with $n s s-\mathrm{K}^{+}$in both winter and summer (Fig. 7a, b) whereas OC showed good correlation $\left(r^{2}=\sim 7\right.$ ), except in summer nighttime (Fig. 7c, d). These correlations suggest that carbonaceous components in Chennai aerosols might be mainly originated from biofuel/biomass burning. The weak correlation between OC and $n s s-\mathrm{K}^{+}$in summer nighttime indicates an additional source, probably higher plant emissions, which only contribute to OC.

The relations of EC and OC were positive with levoglucosan in both winter and summer (Fig. 7). However, the plots between EC and levoglucosan were highly scattered (Fig. 7e, f). It is likely that the emission factors of EC and levoglucosan are highly dependent on type of biomass and burn rate, especially in Asian biofuels as discussed earlier (Stone et al., 2010). In contrast, OC showed a strong correlation $\left(r^{2}=0.83\right)$ in winter daytime and medium correlations in rest of the campaigns OC $\left(r^{2} \geq 0.3\right)$, suggesting a larger fraction of OC (maybe EC too) is derived from biomass burning rather than fossil fuel combustion.

\subsubsection{Relations between selected carbonaceous components}

As shown in Fig. 8, EC and OC correlate well in winter nighttime and summer daytime and weakly in winter daytime but no correlation was found in summer nighttime, suggesting a significant contribution of EC and OC from common sources; biofuel/biomass burning. However, the weak and no correlation in winter daytime and summer nighttime, respectively, indicate an additional source(s) for either. As noted earlier, land/sea breeze circulation causes the flow of marine and inland air masses onshore and offshore in dayand night-time, respectively. This may weaken the correlation in winter daytime. Marine sources contribute to OC only, but not EC (except ship exhaust), whereas inland air masses may be enriched with both. In fact, the higher ends of EC in winter nighttime were almost twice to that of daytime whereas those of OC were just about $10 \%$ (see Table 1) that indicate the significant contribution of $\mathrm{OC}$ from marine sources in daytime.

In summer daytime, EC contributions may be as significant as nighttime although sea breeze uplifts marine air masses. The significant mixing of inland air masses is very likely as the winds prevail from southwest in summer (Pavuluri et al., 2010a), passing over southern part of the Indian subcontinent, and hence the influence of marine air masses on EC and OC distributions may be insignificant. Interestingly, EC concentrations were almost constant in summer day- and night-time whereas the higher ends of $\mathrm{OC}$ were almost $45 \%$ to those of daytime (see Table 1), indicating
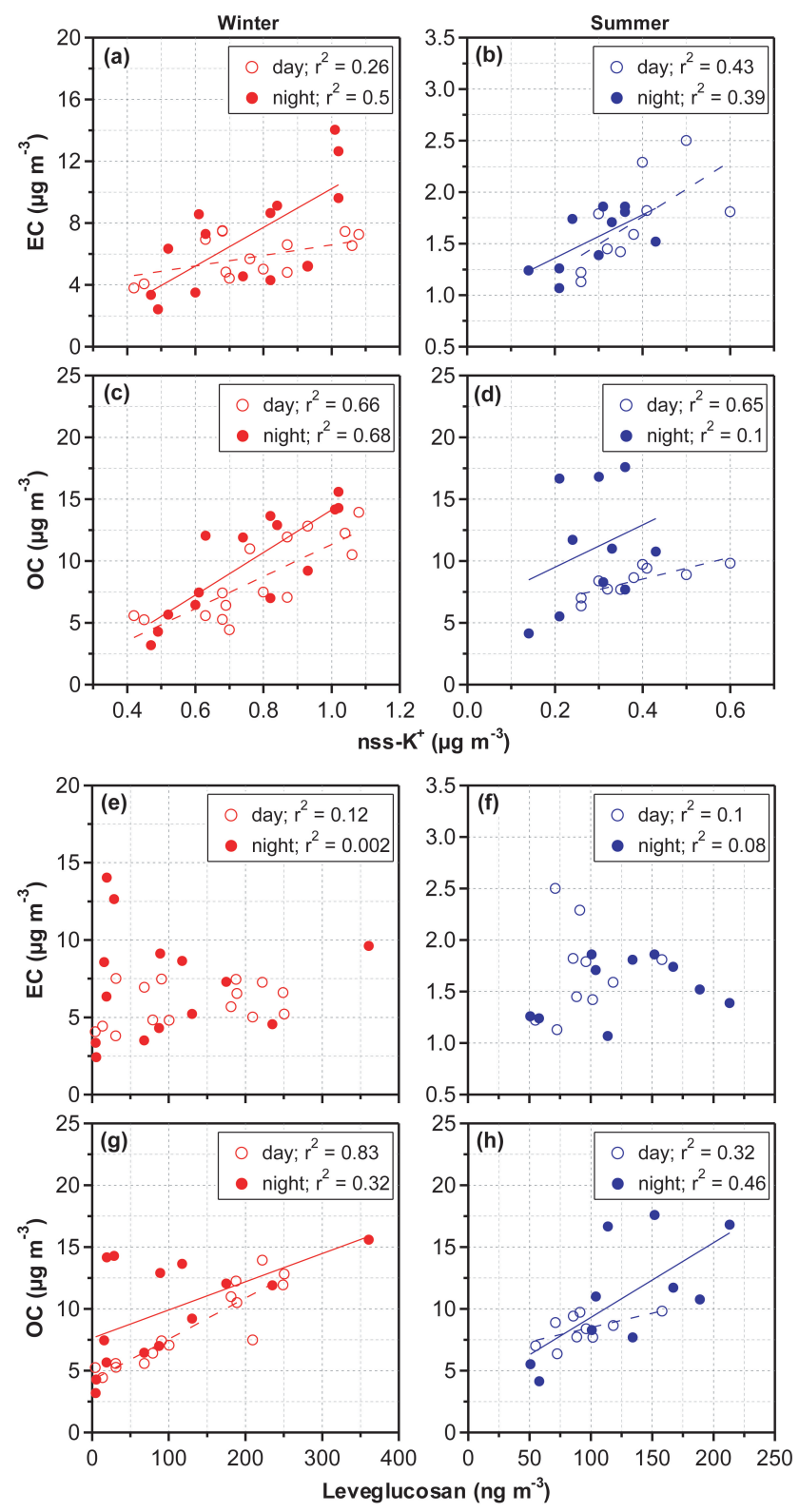

Fig. 7. Scatter plots of EC and OC with nss- $\mathrm{K}^{+}(\mathbf{a}, \mathbf{b}, \mathbf{c}$ and $\mathbf{d})$ and levoglucosan $(\mathbf{e}, \mathbf{f}, \mathbf{g}$ and $\mathbf{h})$ in the tropical Indian aerosol $\left(\mathrm{PM}_{10}\right)$ samples collected on day- and night-time bases in winter (23 January to 6 February) and summer (22-31 May) 2007 from Chennai, India. Levoglucosan data is obtained from Fu et al., 2010.

a larger contribution of $\mathrm{OC}$ in nighttime. In fact, emission of VOCs from tropical plants in India is higher in summer than winter (Padhey and Varshaney, 2005). Pavuluri et al. (2010a) also found high concentrations of long-chain $\left(\mathrm{C}_{9^{-}}\right.$ $\mathrm{C}_{12}$ ) diacids in summer nighttime, which are likely formed by oxidation of unsaturated fatty acids that are emitted from higher plants. Hence, we presume that production of secondary organic aerosol by the photochemical oxidation of VOCs emitted from higher plants might be significant in 


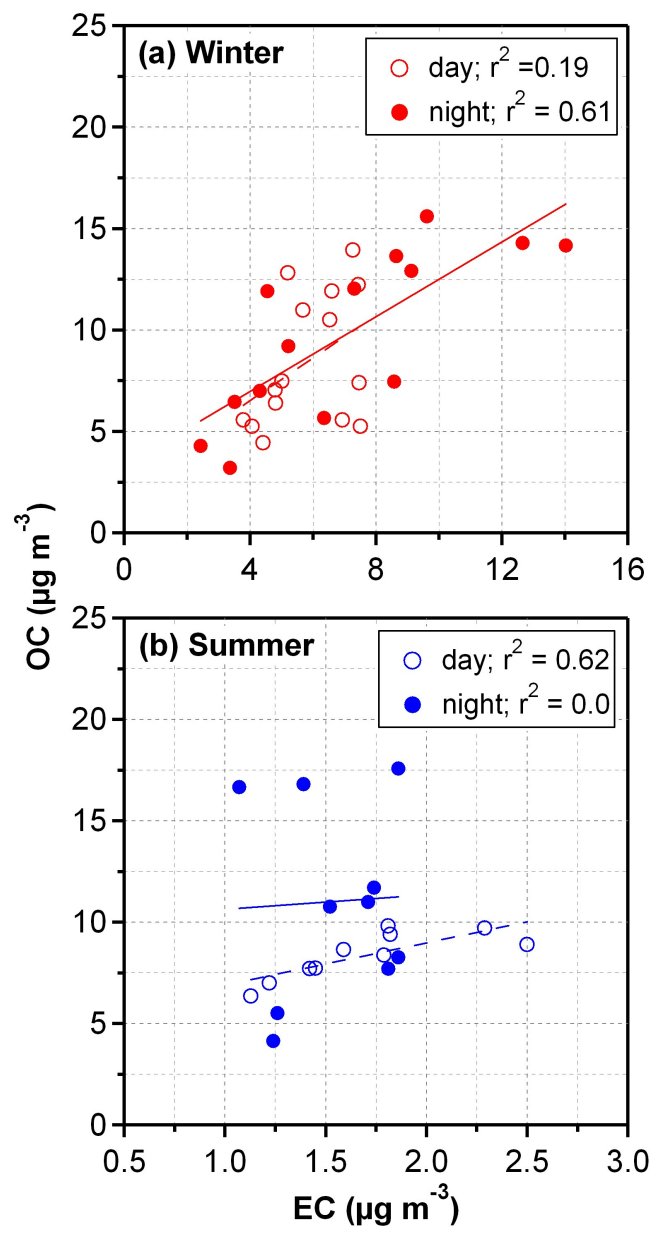

Fig. 8. Scatter plots between EC and OC in the tropical Indian aerosol $\left(\mathrm{PM}_{10}\right)$ samples collected on day- and night-time bases in (a) winter (23 January to 6 February) and (b) summer (22-31 May), 2007 from Chennai, India.

inland region during daytime and thus the inland air masses become enriched with OC that are transported to sampling site in nighttime by land breeze.

It is generally believed that SOC is nearly equivalent to WSOC because secondarily produced OC preferably contains the oxygenated chemical functional groups that are water-soluble, although this has not been experimentally demonstrated for ambient air. Kondo et al. (2007) reported very high correlations $\left(r^{2}=0.87-0.93\right)$ between WSOC and total carbon concentrations of oxygenated organic aerosols (defined as OOC). Miyazaki et al. (2006) found good correlations $\left(r^{2}=0.61-0.79\right)$ between SOC and WSOC in Tokyo aerosols, where fossil fuel combustion was expected to be the major source. The scatter plots between SOC and WSOC in Chennai aerosols in winter and summer are shown in Fig. 9. We found high and medium correlations between SOC and WSOC in winter daytime and in winter and summer nighttime, respectively, but weak in summer daytime (Fig. 9). Fur-

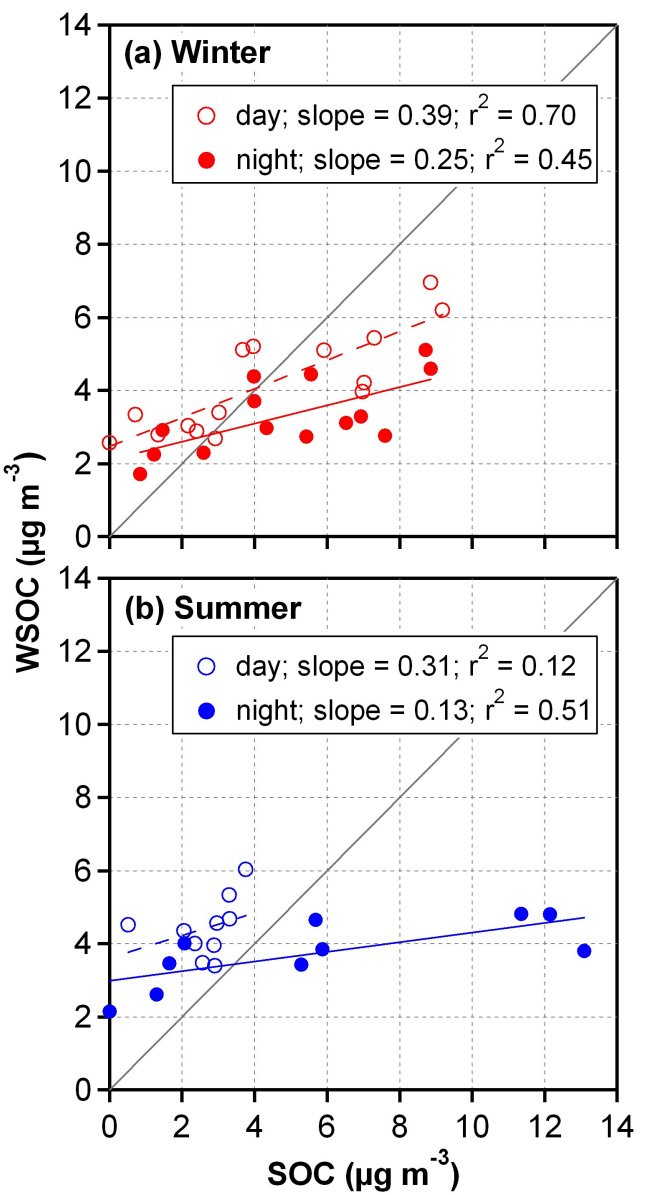

Fig. 9. Linear regression plots between SOC and WSOC in the tropical Indian aerosol $\left(\mathrm{PM}_{10}\right)$ samples collected on day- and nighttime bases in (a) winter (23 January to 6 February) and (b) summer (22-31 May), 2007 from Chennai, India.

ther, the correlation coefficients are close to those reported for Tokyo aerosols (Miyazaki et al., 2006).

Slopes (0.13-0.39) of the correlations between SOC and WSOC in Chennai aerosols were lower in nighttime than daytime in both winter and summer (Fig. 9). They were twice to five times lower than those $(0.61-0.74)$ reported in Tokyo aerosols (Miyazaki et al., 2006). These low slope values in Chennai aerosols indicate that most of the SOC is not water-soluble. It is likely because some SOC compounds are considered to have large carbon-hydrogen chain $\left(\geq \mathrm{C}_{9}\right.$ ) and functional groups, leading to water-insolubility (Saxena and Hildemann, 1996). Interestingly, the increase in WSOC was insignificant with increasing SOC in summer nighttime aerosols, suggesting that SOC originated from biofuel/biomass burning and terrestrial plant emissions are less water-soluble. Thus, the mass concentration ratios and linear relations of selected ionic species, carbonaceous components and organic marker species indicate that Chennai aerosols are mainly derived by biofuel/biomass burning and 
secondary production during long-range atmospheric transport from distant source regions in South and Southeast Asia.

\subsection{Diurnal variations of carbonaceous and ionic components: land/sea breeze circulation}

All carbonaceous and ionic components showed a diurnal distribution in both winter and summer, except for few cases (Figs. 2 and 3; Table 1). The diurnal distributions of EC and $\mathrm{OC}$ were similar with nighttime maxima, except for few cases, but opposite on 28, 30 and 31 May (Fig. 2a and b). WSOC and WIOC showed day- and night-time maxima, respectively, in both winter and summer (Fig. 2c and d). Interestingly, SOC also showed nighttime maxima in opposite to that of WSOC (Fig. 2f) whereas POC did not show any trend (Fig. 2e). Concentrations of $\mathrm{MSA}^{-}, \mathrm{SO}_{4}^{2-}, \mathrm{K}^{+}, \mathrm{Mg}^{2+}$ and $\mathrm{Ca}^{2+}$ showed daytime maxima whereas those of $\mathrm{Cl}^{-}$ and $\mathrm{NO}_{3}^{-}$showed opposite trend, except for few cases, in both winter and summer (Fig. 3). In contrast, $\mathrm{Na}^{+}$showed daytime maxima in winter but daytime minima in summer (Fig. 3e) whereas $\mathrm{NH}_{4}^{+}$showed an opposite trend to that of $\mathrm{Na}^{+}$(Fig. 3f).

These diurnal changes may be caused by land/sea breeze circulation because wind speed and wind direction on the near surface showed a clear diurnal oscillation during the campaigns (Pavuluri et al., 2010a). The onset of sea breeze in daytime causes the onshore flow of marine air masses (Lu and Turco, 1994; Miller et al., 2003) and develops the thermal internal boundary layer (TIBL) extending up to 50$100 \mathrm{~m}$ above ground level under the atmospheric boundary layer (ABL) at the coast in Chennai region (Srinivas et al., 2007) that restricts the vertical distribution of pollutants. In contrast, the TIBL disappears and the ABL moves down after the onset of the land breeze in nighttime. In addition, the oxidant concentration may stay high under nighttime smog condition at surface level (Miller et al., 2003) that may promote the in-situ oxidation processes.

The onset of land breeze that transports the inland air masses, enriched with anthropogenic emissions, to the sampling site may increase the EC, OC and WIOC concentrations in nighttime whereas in daytime, their concentrations might be reduced by dilution with aloft marine air masses. The daytime maxima of EC in summer, for few cases, is probably due to mixing of polluted inland air masses as the winds prevailed from southwest (Pavuluri et al., 2010a). The daytime maxima of WSOC are likely as most of WSOC considered to be secondary that may be produced under strong solar radiation in daytime by in-situ photochemical processes. Further, the long-range transported marine aerosols may also be enriched with WSOC. In contrast, the nighttime maxima of SOC (some SOC compounds may not be watersoluble; Saxena and Hildemann, 1996) might be due to larger contributions of long-range transported aerosols because vertical mixing of the aged air masses that were accumulated between TIBL and ABL is significant once TIBL disappears by the onset of land breeze in nighttime.

On the other hand, the onset of sea breeze in daytime may uplift aged aerosols that are accumulated over oceanic region together with inland air masses transported offshore in previous night. The aged aerosols may be enriched with secondary species such as $\mathrm{MSA}^{-}, \mathrm{SO}_{4}^{2-}$ and WSOC as well as primary pollutants; $\mathrm{K}^{+}$and $\mathrm{Mg}^{2+}$ and $\mathrm{Ca}^{2+}$. The former two species are produced by photooxidation of DMS emitted either from oceanic phytoplankton and/or biomass burning, whereas $\mathrm{K}^{+}$is emitted from biomass burning and $\mathrm{Mg}^{2+}$ and $\mathrm{Ca}^{2+}$ are from crustal sources. In addition, local emissions from biofuel burning and crustal sources might have also influenced the concentrations of pollutants to some extent. Thus, $\mathrm{MSA}^{-}, \mathrm{SO}_{4}^{2-}, \mathrm{K}^{+}, \mathrm{Mg}^{2+}$ and $\mathrm{Ca}^{2+}$ might become predominant in daytime, and hence aerosols become relatively more acidic in daytime than nighttime (Fig. 4). Conversely, $\mathrm{Cl}^{-}$showed lower concentrations in daytime than nighttime, because $\mathrm{HCl}$ is released from $\mathrm{NaCl}$ by the reaction with acidic sulfur species and is attached to aerosols after the reaction with $\mathrm{NH}_{3}$ (Hara et al., 2004). Local emissions, such as fossil fuel combustion, might be the major source of $\mathrm{NO}_{3}^{-}$ and hence, it showed a peak in nighttime due to land breeze.

The daytime maxima of $\mathrm{Na}^{+}$in winter are caused by sea breeze that brings marine air masses. Although its nighttime maxima in few cases during summer (Fig. 3e) are ambiguous, we assume that the sea-salt particles might significantly accumulate between TIBL and ABL during development of the TIBL and their atmospheric level become higher due to vertical dispersion of pollutants, after TIBL disappears in nighttime. As described in Pavuluri et al. (2010b), animal excreta and biofuel/biomass burning are two major sources of $\mathrm{NH}_{4}^{+}$. Hence, the air masses uplifted by land breeze in nighttime during winter may be enriched with $\mathrm{NH}_{4}^{+}$and those by sea breeze in daytime during summer might become enriched with $\mathrm{NH}_{4}^{+}$as they passed over south Indian subcontinent where cow-dung combustion and animal excreta are more important than in central India (Reddy and Venkataraman, 2002b; Garg et al., 2001).

\section{Summary and conclusions}

The tropical Indian aerosol $\left(\mathrm{PM}_{10}\right)$ samples collected at Chennai on day- and night-time bases in winter and summer, 2007 were studied for carbonaceous and ionic components. $\mathrm{EC}$ and ionic components showed higher concentrations in winter than summer, but $\mathrm{OC}$ was rather constant in both seasons. EC and OC showed similar diurnal variations with nighttime maxima in winter but EC showed daytime maxima for few cases in summer. $\mathrm{SO}_{4}^{2-}$ was the most abundant ionic species followed by $\mathrm{NH}_{4}^{+}$. $\mathrm{MSA}^{-}, \mathrm{SO}_{4}^{2-}, \mathrm{K}^{+}, \mathrm{Mg}^{2+}$ and $\mathrm{Ca}^{2+}$, showing daytime maxima. In contrast, $\mathrm{Cl}^{-}$and $\mathrm{NO}_{3}^{-}$showed nighttime maxima in both winter and summer, 
except for few cases. On average, estimated SOC was found to be similar in both winter and summer.

The seasonal changes in mass fractions of EC, OM and ionic species and the comparisons of EC and OC concentrations with those reported for aerosols from other locale in South Asia together with air mass trajectories suggest that the biofuel/biomass burning is a major source of South and Southeast Asian aerosols. The mass concentration ratios of selected components, particularly nss- ${ }^{+}$, nss- $\mathrm{SO}_{4}^{2-}$, nss$\mathrm{Ca}^{2+}$ and $\mathrm{NO}_{3}^{-}$to $\mathrm{EC}$ and $\mathrm{OC}$ and the relations between $\mathrm{EC}$, $\mathrm{OC}$ and marker species (nss- $\mathrm{K}^{+}$and levoglucosan) also inferred that the biofuel/biomass burning as the major source of atmospheric aerosols in this region. The high concentrations of SOC, WSOC/OC ratios and positive correlations between SOC and WSOC indicated that secondary production of organic aerosols during long-range transport is also an important source of the tropical Indian aerosols. The data sets reported here could serve as baseline observation of carbonaceous aerosols for southern part of the Indian subcontinent, which could contribute to regional climate and air quality models.

Acknowledgements. This study was partly supported by a Grantin-aid No. 19204055 from the Japan Society for the Promotion of Science (JSPS) and the Environment Research and Technology Development Fund (B-0903) of the Ministry of the Environment, Japan. We appreciate the financial support of a JSPS Fellowship to C. M. P. We also thank R. A. Damodar and K. Jagannathan for their support in the sample collection.

Edited by: N. Mihalopoulos

\section{References}

Ackerman, A. S., Toon, O. B., Stevens, D. E., Heymsfield, A. J., Ramanathan, V., and Welton, E. J.: Reduction of tropical cloudiness by soot, Science, 288, 1042-1047, 2000.

Aggarwal, S. G. and Kawamura, K.: Molecular distributions and stable carbon isotopic compositions of dicarboxylic acids and related compounds in aerosols from Sapporo, Japan: implications for photochemical aging during longrange atmospheric transport, J. Geophys. Res., 113, D14301, doi:10.1029/2007JD009365, 2008.

Aggarwal, S. G. and Kawamura, K.: Carbonaceous and inorganic composition in long-range transported aerosols over northern Japan: implication for aging of water-soluble organic fraction, Atmos. Environ., 43, 2532-2540, 2009.

Ali-Mohamed, A. Y.: Estimation of inorganic particulate matter in the atmosphere of Isa town, Bahrain, by dry deposition, Atmos. Environ., 25B, 397-405, 1991.

Andreae, M. O.: Soot carbon and excess fine potassium: long-range transport of combustion-derived aerosols, Science, 220, 1148$1151,1983$.

Andreae, M. O. and Merlet, P.: Emission of trace gases and aerosols from biomass burning, Global Biogeochem. Cy., 15, 955-966, 2001.
Babu, S. S. and Moorthy, K. K.: Aerosol black carbon over a tropical coastal station in India, Geophys. Res. Lett., 29(23), 2098, doi:10.1029/2002GL015662, 2002.

Babu, S. S., Satheesh, S. K., and Moorthy, K. K.: Aerosol radiative forcing due to enhanced black carbon at an urban site in India, Geophys. Res. Lett., 29(18), 1880, doi:10.1029/2002GL015826, 2002.

Cao, J. J., Lee, S. C., Ho, K. F., Zhang, X. Y., Zou, S. C., Fung, K., Chow, J. C., and Watson, J. G.: Characteristics of carbonaceous aerosol in Pearl River Delta region, China during 2001 winter period, Atmos. Environ., 37, 1451-1460, 2003.

Carrico, C. M., Bergin, M. H., Shrestha, A. B., Dibb, J. E., Gomes, L., and Harris, J. M.: The importance of carbon and mineral dust to seasonal aerosol properties in the Nepal Himalaya, Atmos. Environ., 37, 2811-2824, 2003.

Castro, L. M., Pio, C. A., Harrison, R. M., and Smith, D. J. T.: Carbonaceous aerosol in urban and rural European atmosphere: estimation of secondary organic carbon concentrations, Atmos. Environ., 33, 2771-2781, 1999.

Cavalli, F., C. Facchini, S. Decesari, M. Mircea, L. Emblico, S. Fuzzi, D. Ceburnis, Y. J. Yoon, C. D. O’Dowd, J.-P. Putaud, and Dell'Acqua, A.: Advances in characterization of size-resolved organic matter in marine aerosol over the North Atlantic, J. Geophys. Res., 109, D24215, doi:10.1029/2004JD005137, 2004.

Chow, J. C., Watson, J. G., Fujita, E. M., Lu, Z., and Lawson, D. R.: Temporal and spatial variations of $\mathrm{PM}_{2.5}$ and $\mathrm{PM}_{10}$ aerosols in the Southern California air quality study, Atmos. Environ., 28, 2061-2080, 1994.

Fu, P. Q., Kawamura, K., Pavuluri, C. M., Swaminathan, T., and Chen, J.: Molecular characterization of urban organic aerosol in tropical India: contributions of primary emissions and secondary photooxidation, Atmos., Chem. Phys., 10, 2663-2689, doi:10.5194/acp-10-2663-2010, 2010.

Garg, A., Bhattacharya, S., Shukla, P. R., and Dadhwal, V. K.: Regional and sectoral assessment of greenhouse gas emissions in India, Atmos. Environ., 35, 2679-2695, 2001.

Gillies, J. A., Gertler, A. W., Sagebiel, J. C., and Dippel, W. A.: On-road particulate matter $\left(\mathrm{PM}_{2.5}\right.$ and $\left.\mathrm{PM}_{10}\right)$ emissions in the Sepulveda tunnel, Los Angels, California, Environ. Sci. Technol., 35, 1054-1063, 2001.

Guazzotti, S. A., Suess, D. T., Coffee, K. R., Quinn, P. K., Bates, T. S., Wisthler, A., Hansel, A., Ball., W. P., Dickerson, R. R., Neusüß, C., Crutzen, P. J., and Prather, K. A.: Characterization of carbonaceous aerosols outflow from India and Arabia: biomass/biofuel burning and fossil fuel combustion, J. Geophys. Res., 108(D15), 4485, doi:10.1029/2002JD003277, 2003.

Gustafsson, Ö., Krusa, M., Zencak, Z., Sheesley, R. J., Granat, L., Engstöm, E., Praveen, P. S., Rao, P. S. P., Leck, C., and Rodhe, H.: Brown clouds over South Asia: biomass or fossil fuel combustion?, Science, 323, 495-498, 2009.

Habib, G., Venkataraman, C., Bond, T. C., and Schauer, J. J.: Chemical, microphysical and optical properties of primary particles from the combustion of biomass fuels, Environ. Sci. Technol., 42, 8829-8834, 2008.

Hara, K., Osada, K., Kido, M., Hayashi, M., Matsunaga, K., Iwasaka, Y., Yamanouchi, T., Hashida, G., and Fukatsu, T.: Chemistry of sea-salt particles and inorganic halogen species in Antarctic regions: compositional differences between coastal and inland stations, J. Geophys. Res., 109, D20208, 
doi:10.1029/2004JD004713, 2004.

Heywood, J. M. and Ramaswamy, V.: Global sensitivity studies of the direct radiative forcing due to anthropogenic sulfate and black carbon aerosols, J. Geophys. Res., 103(D6), 6043-6058, 1998.

Jacobson, M. Z.: Strong radiative heating due to the mixing of black carbon in atmospheric aerosols, Nature, 409, 695-697, 2001.

Kanakidou, M., Seinfeld, J. H., Pandis, S. N., Barnes, I., Dentener, F. J., Facchini, M. C., Van Dingenen, R., Ervens, B., Nenes, A., Nielsen, C. J., Swietlicki, E., Putaud, J. P., Balkanski, Y., Fuzzi, S., Horth, J., Moortgat, G. K., Winterhalter, R., Myhre, C. E. L., Tsigaridis, K., Vignati, E., Stephanou, E. G., and Wilson, J.: Organic aerosol and global climate modelling: a review, Atmos. Chem. Phys., 5, 1053-1123, doi:10.5194/acp-5-1053-2005, 2005.

Kawamura, K. and Usukura, K.: Distributions of low molecular weight dicarboxylic acids in the North Pacific aerosol samples, J. Oceanogr., 49, 271-283, 1993.

Keene, W. C., Lobert, J. M., Crutzen, P. J., Maben, J. R., Scharffe, D. H., Landmann, T., Hely, C., and Brain, C.: Emissions of major gaseous and particulate species during experimental burns of southern African biomass, J. Geophys. Res., 111, D04301, doi:10.1029/2005JD006319, 2006.

Khemani, L. T., Momin, G. A., Naik, M. S., Kumar, R. V., and Murthy, B. H. V. R.: Chemical composition and size distribution of atmospheric aerosols over the Deccan Plateau, India, Tellus, 34, 151-158, 1982.

Kiehl, J. T. and Briegleb, B. P.: The relative roles of sulfate aerosols and greenhouse gases in climate forcing, Science, 260, 311-314, 1993.

Kiss, G., Varga, B., Galambos, I., and Ganszky, I.: Characterization of water-soluble organic matter isolated from atmospheric fine aerosol, J. Geophys. Res., 107(D21), 8339, doi:10.1029/2001JD000603, 2002.

Kondo, Y., Miyazaki, Y., Takegawa, N., Miyakawa, T., Weber, R. J., Jimenez, J. L., Zhang, Q., and Worsnop, D. R.: Oxygenated and water-soluble organic aerosols in Tokyo, J. Geophys. Res., 112, D01203, doi:10.1029/2006JD007056, 2007.

Latha, K. M. and Badrinath, K. V. S.: Black carbon aerosols over tropical urban environment-a case study, Atmos. Res., 69, 125133, 2003.

Lelieveld, J., Crutzen, P. J., Ramanathan, V., Andreae, M. O., Brenninkmeijer, C. A. M., Campos, T., Cass, G. R., Dickerson, R. R., Fischer, H., de Gouw, J. A., Hansel, A., Jefferson, A., Kley, D., de Laat, A. T. J., Lal, S., Lawrence, M. G., Lobert, J. M., MayolBracero, O. L., Mitra, A. P., Novakov, T., Oltmans, S. J., Prather, K. A., Reiner, T., Rodhe, H., Scheeren, H. A., Sikka, D., and Williams, J.: The Indian Ocean experiment: widespread air pollution from South and Southeast Asia, Science, 291, 1031-1036, 2001.

Lim, H.-J. and Turpin, B. J.: Origins of primary and secondary organic aerosol in Atlanta: results of time-resolved measurements during the Atlanta supersite experiment, Environ. Sci. Technol., 36, 4489-4496, 2002.

Lu, R. and Turco, R. P.: Air pollutant transport in a coastal environment. Part I: two-dimensional simulations of sea-breeze and mountain effects, J. Atmos. Sci., 51(15), 2285-2308, 1994.

Mayol-Bracero, O. L., Gabriel, R., Andreae, M. O., Kirchstetter, T. W., Novakov, T., Ogren, J., Sheridan, P., and Streets, D. G.:
Carbonaceous aerosols over the Indian Ocean during the Indian Ocean Experiement (INDOEX): chemical characterization, optical properties, and probable sources, J. Geophys. Res., 107(D19), 8030, doi:10.1029/2000JD000039, 2002.

Meinardi, S., Simpson, I. J., Blake, N. J., Blake, D. R., and Rowland, F. S.: Dimethyl disulfide (DMDS) and dimethyl sulfide (DMS) emissions from biomass burning in Australia, Geophys. Res. Lett., 30(9), 1454, doi:10.1029/2003GL016967, 2003.

Menon, S., Hansen, J., Nazarenko, L., and Luo, Y.: Climate effects of black carbon aerosols in China and India, Science, 297, 2250 2253, 2002.

Miller, S. T. K., Keim, B. D., Talbot, R. W., and Mao, H.: Sea breeze: structure, forecasting, and impacts, Rev. Geophys. 41(3), 1011, doi:10.1029/2003RG000124, 2003.

Miyazaki, Y., Kondo, Y., Takegawa, N., Komazaki, Y., Fukuda, M., Kawamura, K., Mochida, M., Okuzawa, K., and Weber, R. J.: Time-resolved measurements of water-soluble organic carbon in Tokyo, J. Geophys. Res., 111, D23206, doi:10.1029/2006JD007125, 2006.

Miyazaki, Y., Aggarwal, S. G., Singh, K., Gupta, P. K., and Kawamura, K.: Dicarboxylic acids and water-soluble organic carbon in aerosols in New Delhi, India in winter: Characteristics and formation processes, J. Geophys. Res., 114, D19206, doi:10.1029/2009JD011790, 2009.

Mouli, P. C., Mohan, S. V., and Reddy, S. J.: Chemical composition of atmospheric aerosol $\left(\mathrm{PM}_{10}\right)$ at asemi-arid urban site: influence of terrestrial sources, Environ. Monitor. Assess., 117, 291-305, 2006.

Negi, B. S., Sadasivan, S., and Mishra, U. C.: Aerosol composition and sources in urban areas in India, Atmos. Environ., 21, 12591266, 1987.

Novakov, T., Andreae, M. O., Gabriel, R., Kirchstetter, T. W., Mayol-Bracero, O. L., and Ramanathan, V.: Origin of carbonaceous aerosols over the tropical Indian Ocean: biomass burning or fossil fuels?, Geophys. Res. Lett., 27(24), 4061-4064, 2000.

Olivier, J. G. J., Bouwman, A. F., Van der Hoek, K. W., and Berdowski, J. J. M.: Global air emission inventories for anthropogenic sources of $\mathrm{NO}_{\mathrm{x}}, \mathrm{NH}_{3}$ and $\mathrm{N}_{2} \mathrm{O}$ in 1990, Environ. Pollut., 102(S1), 135-148, 1998.

Padhy, P. K. and Varshney, C. K.: Emission of volatile organic compounds (VOC) from tropical plant species in India, Chemosphere, 59, 1643-1653, 2005.

Parmar, R. S., Satsangi, G. S., Kumari, M., Lakhani, A., Srivastava, S. S., and Prakash, S.: Study of size distribution of atmospheric aerosol at agra, Atmos. Environ., 35, 693-702, 2001.

Pavuluri, C. M., Kawamura, K., and Swaminathan,T.: Watersoluble organic carbon, dicarboxylic acids, ketoacids and $\alpha$ dicarbonyls in the tropical Indian aerosols, J. Geophys., Res., 115, D11302, doi:10.2019/2009JD012661, 2010a.

Pavuluri, C. M., Kawamura, K., Tachibana, E., and Swaminathan, T.: Elevated nitrogen isotope ratios of tropical Indian aerosols from Chennai: implication for the origins of aerosol nitrogen in South and Southeast Asia, Atmos. Environ., 44, 3597-3604, $2010 b$.

Ram, K., Sarin, M. M., and Hegde, P.: Atmospheric abundances of primary and secondary carbonaceous species at two high-altitude sites in India: sources and temporal variability, Atmos. Environ., 42, 6785-6796, 2008.

Ram, K., Sarin, M. M., and Tripathi, S. N.: A 1 year record of car- 
bonaceous aerosols from urban site in the Indo-Gangetic plain: characterization, sources and temporal variability, J. Geophys. Res., Res., 115, D24313, doi:10.1029/2010JD014188, 2010.

Ramanathan, V., Crutzen, P. J., Kiehl, J. T., and Rosenfeld, D.: Aerosols, Climate, and the hydrological cycle, Science, 294, 2119-2124, 2001.

Reddy, M. S. and Venkataraman, C.: Inventory of aerosol and sulphur dioxide emissions from India: I-fossil fuel combustion, Atmos. Environ., 36, 677-697, 2002a.

Reddy, M. S. and Venkataraman, C.: Inventory of aerosol and sulphur dioxide emissions from India. Part II - biomass combustion, Atmos. Environ., 36, 699-712, 2002 b.

Rengarajan, R., Sarin, M. M., and Sudheer, A. K.: Carbonaceous and inorganic species in atmospheric aerosols during wintertime over urban and high-altitude sites in North India, J. Geophys. Res., 112, D21307, doi:10.1029/2006JD008150, 2007.

Salam, A., Bauer, H., Kassin, K., Ullah, S. M., and Puxbaum, H.: Aerosol chemical characteristics of a mega-city in Southeast Asia (Dhaka-Bangladesh), Atmos. Environ., 37, 2517-2528, 2003.

Satheesh, S. K. and Ramanathan, V.: Large differences in tropical aerosol forcing at the top of the atmosphere and Earth's surface, Nature, 405, 60-63, 2000.

Saxena, P. and Hildemann, L. M.: Water-soluble organics in atmospheric particles: a critical review of the literature and application of thermodynamics to identify candidate compounds, J. Atmos. Chem., 24, 57-109, 1996.

Saxena, P., Hildemann, L. M., McMurry, P. H., and Seinfeld, J. H.: Organics alter hygroscopic behavior of atmospheric particles, J. Geophys. Res., 100(D9), 18755-18770, 1995.

Sharma, V. K. and Patil, R. S.: Size distribution of atmospheric aerosol and their source identification using factor analysis in Bombay, India, Atmos. Environ., 26, 135-141, 1992.

Sillanpää, M., Frey, A., Hillamo, R., Pennanen, A. S., and Salonen, R. O.: Organic, elemental and organic carbon in particulate of six urban environments in Europe, Atmos. Chem. Phys., 5, 28692879, doi:10.5194/acp-5-2869-2005, 2005.

Smith, D. J. T., Harrison, R. M., Luhana, L., Pio, C. A., Castro, L. M., Tariq, M. N., Hayat, S., and Quraishi, T.: Concentrations of particulate airborne polycyclic aromatic hydrocarbons and metals collected in Lahore, Pakistan, Atmos. Environ., 30(23), 4031-4040, 1996.

Srinivas, C. V., Venkatesan, R., Somayaji, K. M., and Singh, A. B.: A numerical study of sea breeze circulation observed at a tropical site Kalpakkam on the east coast of Inda under different synoptic flow situations, J. Earth Syst. Sci., 115(5), 557-574, 2006.

Srinivas, C. V., Venkatesan, R., and Singh, A. B.: Sensitivity of mesoscale simulations of land-sea breeze to boundary layer turbulence parameterization, Atmos. Environ., 41, 2534-2548, 2007.

Stone, E. A., Schauer, J. J., Pradhan, B. B., Dangol, P. M., Habib, G., Venkataraman, C., and Ramanathan, V.: Characterization of emissions from South Asian biofuels and application to source apportionment of carbonaceous aerosol in the Himalayas, J. Geophys. Res., 115, D06301, doi:10.1029/2009JD011881, 2010.
Streets, D. G., Yarber, K. F., Woo, J.-H, and Carmichael, G. R.: Biomass burning in Asia: Annual and seasonal estimates and atmospheric emissions, Global Biogeochem. Cy., 17(4), 1099, doi:10.1029/2003GB002040, 2003.

Sudheer, A. K. and Sarin, M. M.: Carbonaceous aerosols in MABL of Bay of Bengal: influence of continental outflow, Atmos. Environ., 42, 4089-4100, 2008.

Sun, J. and Ariya, P. A.: Atmospheric organic and bio-aerosols as cloud condensation nuclei $(\mathrm{CCN})$ : a review, Atmos. Environ., 40, 795-820, 2006.

Tata Energy Research Institute, Tata energy directory and data yearbook 1996-1997, New Delhi, India, 1997.

Turpin, B. J. and Huntzicker, J. J.: Identification of secondary organic aerosol episodes and quantification of primary and secondary organic aerosol concentrations during SCAQS, Atmos. Environ., 29(23), 3527-3544, 1995.

Venkataraman, C., Reddy, C. K., Josson, S., and Reddy, M. S.: Aerosol size and chemical characteristics at Mumbai, India, during the INDOEX-IFP (1999), Atmos. Environ., 36, 1979-1991, 2002.

Venkataraman, C., Habib, G., Eiguren-Fernandez, A., Miguel, A. H., and Friedlander, S. K.: Residential biofuels in South Asia: carbonaceous aerosol emissions and climate impacts, Science, 307, 1454-1456, 2005.

von Glasow, R. and Crutzen, P. J.: Model study of multiphase DMS oxidation with a focus on halogens, Atmos. Chem. Phys., 4, 589608, doi:10.5194/acp-4-589-2004, 2004.

Wang, H., Kawamura, K., and Shooter, D.: Carbonaceous and ionic components in wintertime atmospheric aerosols from two New Zealand cities: implications for solid fuel combustion, Atmos. Environ., 39, 5865-5875, 2005.

Watson, J. G., Chow, J., and Houk, J. E.: $\mathrm{PM}_{2.5}$ source profile for vehicle exhaust, vegetative burning, geological material, and coal burning in Northwestern Colorado during 1995, Chemosphere, 43, 1141-1151, 2001.

World Bank: World development report 1999/2000: entering into the 21 st century, Washington, DC, USA, 2000.

Yamasoe, M. A., Artaxo, P., Miguel, A. H., and Allen, A. G.: Chemical composition of aerosol particles from direct emissions of vegetation fires in the Amazon Basin: water-soluble species and trace elements, Atmos. Environ., 34, 1641-1653, 2000.

Yang, H., Xu, J., Wu, W.-S., Wan, C. H., and Yu, J. Z.: Chemical characterization of water-soluble organic aerosols at Jeju Island collected during ACE-Asia, Environ. Chem., 1, 13-17, doi:10.1071/EN04006, 2004.

Yang, H., Yu, J. Z., Ho, S. S. H., Xu, J., Wu, W.-S., Wan, C. H., Wang, X., Wang, X., and Wang, L.: The chemical composition of inorganic and carbonaceous materials in $\mathrm{PM}_{2.5}$ in Nanjing, China, Atmos. Environ., 39, 3735-3749, 2005.

Yu, S., Dennis, R. L., Bhave, P. V., and Eder, B. K.: Primary and secondary organic aerosols over the United States: estimates on the basis of observed organic carbon (OC) and elemental carbon (EC), and air quality modeled primary OC/EC ratios, Atmos. Environ., 38, 5257-5268, 2004. 